\title{
Organophosphorus Flame Retardants: A Global Review of Indoor Contamination and Human Exposure in Europe and Epidemiological Evidence
}

\author{
Zohra Chupeau 1,2, Nathalie Bonvallot ${ }^{2,3}$, Fabien Mercier 2,3 (1) Barbara Le Bot ${ }^{2,3}$, \\ Cecile Chevrier ${ }^{1,2}$ and Philippe Glorennec ${ }^{2,3, *(\mathbb{D})}$ \\ 1 INSERM-Institut National de la Santé et de la Recherche Médicale, F-75000 Paris, France; \\ zohra.chupeau@univ-rennes1.fr (Z.C.); cecile.chevrier@univ-rennes1.fr (C.C.) \\ 2 IRSET-Institut de Recherche en Santé, Environnement et Travail, UMR1085, F-35000 Rennes, France; \\ Nathalie.Bonvallot@ehesp.fr (N.B.); Fabien.Mercier@ehesp.fr (F.M.); barbara.lebot@ehesp.fr (B.L.B.) \\ 3 EHESP-Ecole des Hautes Etudes en Santé Publique, F-35000 Rennes, France \\ * Correspondence: philippe.glorennec@ehesp.fr
}

Received: 21 August 2020; Accepted: 9 September 2020; Published: 15 September 2020

\begin{abstract}
We aimed to identify high-priority organophosphorus flame retardants for action and research. We thus critically reviewed literature between 2000 and 2019 investigating organophosphorus flame retardants' presence indoors and human exposure in Europe, as well as epidemiological evidence of human effects. The most concentrated compounds indoors were tris(2-butoxyethyl)phosphate (TBOEP), tris(1-chloro-2-propyl)phosphate (TCIPP), tris(2,3-dichloropropyl)phosphate (TDCIPP). TBOEP and TCIPP were the most consistently detected compounds in humans' urine, hair or breast milk as well as tris (butyl) phosphate (TNBP) and tris (phenyl) phosphate (TPHP). Notably, epidemiological evidence concerned reprotoxicity, neurotoxicity, respiratory effects and eczema risk for TDCIPP, eczema increase for TBOEP, and neurodevelopmental outcomes for Isopropylated triarylphosphate isomers (ITPs). Given the ubiquitous presence indoors and the prevalence of exposure, the growing health concern seems justified. TDCIPP and TPHP seem to be of particular concern due to a high prevalence of exposure and epidemiological evidence. TBOEP and TNBP require epidemiological studies regarding outcomes other than respiratory or dermal ones.
\end{abstract}

Keywords: environmental health; indoor air quality; epidemiology; biomonitoring; chemical safety; organophosphate ester

\section{Introduction}

Flame retardants are chemical compounds that have, since the 1960s, been added to many products during the manufacturing process [1] with the intention of minimizing the risk of a fire starting, or reducing fire propagation [2]. Polybrominated biphenyls were used in products until they were phased out in 1976. They were replaced by a very similar set of chemicals called polybrominated diphenyl ethers, a family of brominated flame retardants. Polybrominated diphenyl ethers were the most commonly used flame retardants until the early 2000s [3]. They were added to consumer products, including furniture, children's products, and electronics [4]. Because of their negative impacts on both the environment and health, due to their bioaccumulation and persistence properties, they have been classified as persistent organic pollutants (POPs) under the Stockholm Convention and their use has been restricted in Europe since the 2000s [5-8]. Organophosphorus Flame Retardants (OPFRs) were used, among their other uses as plasticizers or lubricants, as a replacement for brominated flame retardants to maintain fire safety standards after their phase-out $[9,10]$. In Europe, the total consumption of flame retardants in 2015 was 498,000 metric 
tons, of which $18 \%$ were phosphorus flame retardants, representing 89,640 metric tons [11] — twice as much as brominated flame retardants. OPFRs are the second-largest flame retardants used in Europe, after aluminum trihydroxide [11]. OPFRs are organic esters of phosphoric acid, containing ether alkyl chains or aryl groups, and may be halogenated or nonhalogenated [4]. Halogenated organophosphates are used as flame retardants, while nonhalogenated organophosphates are mostly used as plasticizers in consumer products, textiles and construction materials [12,13]. More specifically, halogenated organophosphates containing such chlorinated forms as tris(1-chloro-2-propyl)phosphate (TCIPP) or tris(2,3-dichloropropyl)phosphate (TDCIPP) are also widely used in furniture, textiles, building materials, polyurethane foam and electronics. Nonhalogenated flame retardants such as tris(2-butoxyethyl)phosphate (TBOEP), Trimethylphosphate (TMP) or Tris(3,5-xylenyl)phosphate (TXP) are mostly used in floor polishes, coatings, engineering thermoplastics and epoxy resins [10]. All OPFR acronyms used are presented in Table S1.

OPFRs are not chemically bound in products and may release into the environment via volatilization, leaching and/or abrasion [14]. They are ubiquitous in the environment and, since the early 2000s, can be found in water, biota, sediment and soil; because of their widespread use in consumer products, they are especially present in indoor environments in which they partition air and dust [15]. OPFRs have thus the potential to expose a population via the ingestion of dust, inhalation of air or dermal contact with both.

Toxicological studies have observed hazards including neurotoxic and endocrine effects. TMP and tris (phenyl) phosphate (TPHP) are estrogen receptor agonists [16]. Furthermore, several OPFRs (TPHP, TMP, Ethylhexyldiphényl phosphate (EHDPP), Tri-o-cresylphosphate (ToCP), Isodecyl diphenyl phosphate (IDPP), TDCIPP, and Tris(2-chloroethyl)phosphate (TCEP)) have induced a reduction in the proliferation and growth of human neural stem cells, rat neuronal growth and network activity [17].

Considering current use and human health concerns, with increasing numbers of studies being dedicated to OPFRs, several reviews have already been performed. Although these have focused on just one or two aspects (such as contamination, exposure or health effects), it remains important to consider all aspects in order to characterize the public health concern. As regulations differ from one country or group of countries to another, we focused on Europe with the perspective of identifying compounds of concern for (bio)monitoring or regulation.

We reviewed the literature with the following objectives: (i) to identify the compounds of greatest concern in Europe regarding indoor contamination, human exposure and epidemiological evidence and (ii) to identify priority data gaps in knowledge. We therefore reviewed recent European studies dedicated to indoor contaminations and exposures. Because health hazards are not location-specific, we reviewed the epidemiological evidence without geographic restriction.

\section{Materials and Methods}

The search covered the period from 2000 to 2019. This review has compiled OPFR concentrations of indoor air and dust in Europe, human intake in Europe, human exposure in Europe, and epidemiological studies worldwide regardless of location, given the expected low variability in human response. Because the review is ultimately interested in human health, the search was conducted in the PubMed database using the request: organophosphorus flame retardant*[Title/Abstract] OR OPFR[Title/Abstract] OR phosphorus flame retardant*[Title/Abstract] OR phosphate ester flame retardant ${ }^{*}$ [Title/Abstract] OR organophosphate flame[Title/Abstract] OR phosphate flame retardant*[Title/Abstract] OR organophosphate ester flame retardant*[Title/Abstract] OR organophosphate triester*[Title/Abstract] OR organophosphate ester*[Title/Abstract] OR organic flame retardant*[Title/Abstract] OR PFR*[Title/Abstract] OR OPE*[Title/Abstract] OR phosphate triester flame retardant ${ }^{*}[$ Title/Abstract]. A total of 2037 articles were identified and sorted by a single reviewer. Articles that did not match with the review subject or written in a language other than English were excluded on the basis of the title and abstract. Fifty-two articles were selected and classified according to their subject in five categories: "indoor air concentrations", "indoor dust concentrations", 
"human intake estimations", "biological measurements" and "epidemiological studies". With the exception of studies on intake estimations, only studies with at least ten measurements were included, to ensure minimal representativeness.

Regarding publications about indoor air and dust concentration, the following items were retrieved: sampling conditions (country, period and location), sample size, minimal, maximal, mean and median concentrations and references. OPFRs' median concentrations were compared between studies regardless of collection method. Regarding human intake, this review summarizes and compares the intake (or external doses) estimations of several OPFRs via various pathways (ingestion, dermal absorption and inhalation). Regarding publications on biological measurements, the following items were retrieved: metabolite name, parent compound(s), sampling conditions (country, population, size and year), minimum, maximum, mean and median concentrations and references. Regarding epidemiological studies, the following items were retrieved: country, population, and exposure assessment, compounds of interest, health outcomes observed, covariates and human health findings. Studies reporting only a correlation without assessing adjusted association between risk factors and health outcomes were not included.

\section{Results and Discussion}

\subsection{Indoor Contamination}

Thirty-one studies dealing with the contamination of indoor dust and/or air were identified and reviewed. OPFR concentrations with at least ten measurements were investigated in Belgium, the Czech Republic, Denmark, Germany, Norway, Romania, Spain, the Netherlands and the United Kingdom. We noticed that all studies used samples which were collected after 2006. Five studies collected more than 60 samples. In Denmark, Langer et al. (2016) [18] collected 497 dust samples from homes and 151 from daycare centers. Bergh et al. studied 169 air samples in Swedish homes [19]. Luongo and Östman (2016) [20] collected 62 dust and air samples from homes in Sweden, Fromme et al. (2014) [21] collected 63 air samples from German daycare centers and Xu [22] collected 61 air and dust samples from homes in Norway.

\subsubsection{Dust}

A total of 20 studies dealt with the contamination of indoor dust [18-21,23-38]. They are described in detail in the supplemental information (Table S2). Twenty-nine OPFRs were measured, and 26 were detected in the indoor dust of daycare centers, cars, private homes, offices and schools. The median dust concentration of compounds ranged from $<0.0018 \mu \mathrm{g} / \mathrm{g}$ in homes in the United Kingdom [33] to $1600 \mu \mathrm{g} / \mathrm{g}$ in Swedish daycare centers [19]. Concentrations (for detected compounds) are shown in Figure 1 . The ten OPFRs having the highest median concentration, independently of the considered indoor environment, were: TBOEP (median $=1600 \mu \mathrm{g} / \mathrm{g}$ in day care centers in Sweden) $>$ TCIPP (median $=65 \mu \mathrm{g} / \mathrm{g}$ in UK homes) $>$ TDCIPP (median $=31 \mu \mathrm{g} / \mathrm{g}$ in UK cars) $>$ TCEP (median $=30 \mu \mathrm{g} / \mathrm{g}$ in homes in Sweden) $>$ EHDPP $($ median $=29 \mu \mathrm{g} / \mathrm{g}$ in UK classrooms $)>$ TPHP $($ median $=9.79 \mu \mathrm{g} / \mathrm{g}$ in homes in the Netherlands) $>$ tris (butyl) phosphate $($ TNBP $)($ median $=5.60 \mu \mathrm{g} / \mathrm{g}$ in homes in Sweden $)>$ Tri-iso-butylphosphate (TIBP) (median $=5.3 \mu \mathrm{g} / \mathrm{g}$ in homes in Sweden) $>$ Tricresylphosphate (TMPP) (median $=2.7 \mu \mathrm{g} / \mathrm{g}$ in homes in Sweden) $>$ TPHP (median $=2.58 \mu \mathrm{g} / \mathrm{g}$ in homes in The Netherlands).

The paragraph hereafter focuses with more details on studies published since 2012 and not included in the previous review by Wei [39]. The highest OPFR median concentrations were observed in Germany, the UK, Denmark and Sweden. However, the differences between countries may be related to the sample location (daycare centers, cars, private homes, offices and schools). For instance, the higher sum of OPFR concentrations observed in Sweden was explained by a particularly high median concentration of TBOEP in daycare centers (median $=1600 \mu \mathrm{g} / \mathrm{g}$ [19]). The recent studies in homes were conducted in the UK, Sweden, Norway, the Netherlands, Denmark, Germany, the Czech Republic, Spain and Portugal. Almost the same OPFRs were analyzed in the UK, Sweden, 
Norway, the Netherlands, Germany and the Czech Republic, although OPFR concentrations were different. In the UK, TCIPP was the most predominant compound, followed by TBOEP, whereas in Norway and Germany TBOEP was the most predominant compound, followed by TCIPP. In Sweden, TBOEP and TCIPP were the two OPFRs having the highest concentration. In the Czech Republic, TCIPP was the predominant but TBOEP was not analyzed. OPFR concentrations were higher in the UK and Sweden than in other countries, with a median concentration of total OPFRs (with different OPFRs between studies) of $49 \mu \mathrm{g} / \mathrm{g}$ in Sweden [20], $79 \mu \mathrm{g} / \mathrm{g}$ [33] and 27.44 $\mu \mathrm{g} / \mathrm{g}$ [26] in the UK. TBOEP was the most predominant compound in daycare centers studied in Germany and Denmark, with a median concentration 8.5 times higher in Germany. In Denmark, the TBOEP median concentration was followed by the TCEP, TDCIPP and TCIPP median concentrations, while in Germany other OPFRs made a minor contribution (with TDCIPP not measured). Office samples were collected in the UK and Germany, and TCIPP was the most predominant in both countries. It was followed by TBOEP in Germany (not measured in the UK) and EHDPP in the UK. The EHDPP concentration was ten times higher in the UK than in Germany (median $=1.6 \mu \mathrm{g} / \mathrm{g}$ vs. median $=0.14 \mu \mathrm{g} / \mathrm{g}$ ) $[26,31]$. The sum of the OPFR median concentration in the UK was higher than in Germany, mainly because of the high TCIPP concentration. School samples were collected in elementary all-day Austrian schools-only TCEP was measured, with a median concentration of $2.5 \mu \mathrm{g} / \mathrm{g}$ [32]. Samples were collected from cars in the UK, Germany and Spain. OPFR concentrations in the UK were nine times higher than in Germany, and 15 times higher than in Spain. OPFR profiles between the UK and Germany were similar, with TCIPP making a major contribution, followed by TDCIPP and TPHP [26,31]. Two OPFRs were measured in Spain: TPHP and DPHP. Only TPHP was measured in all three countries.

Homes
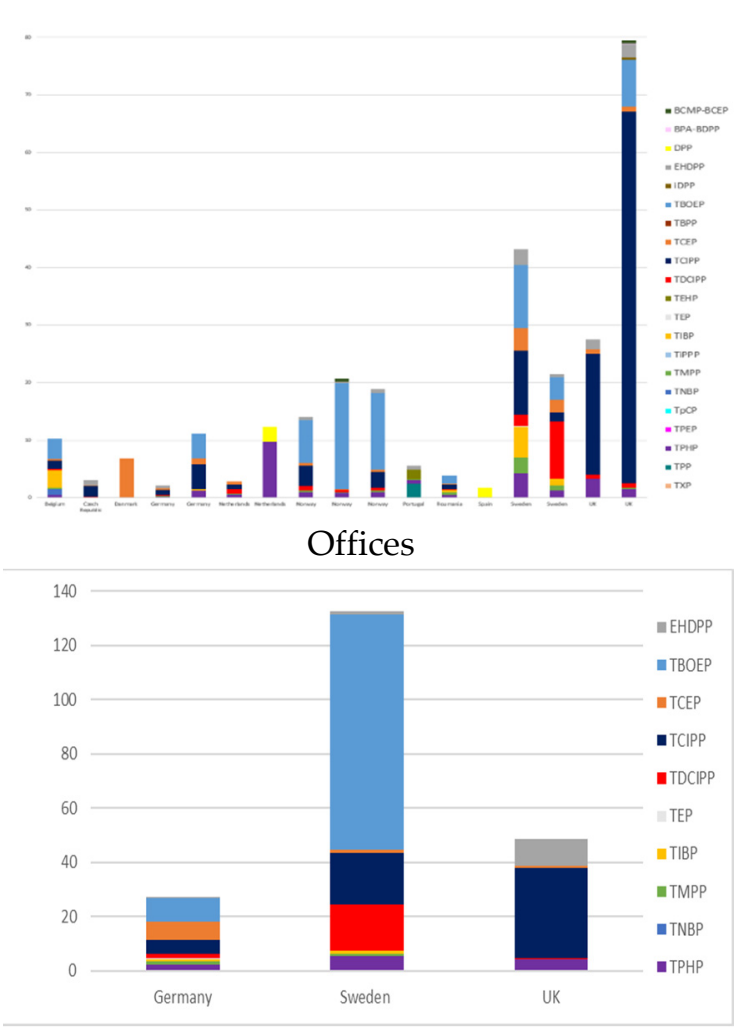

Cars

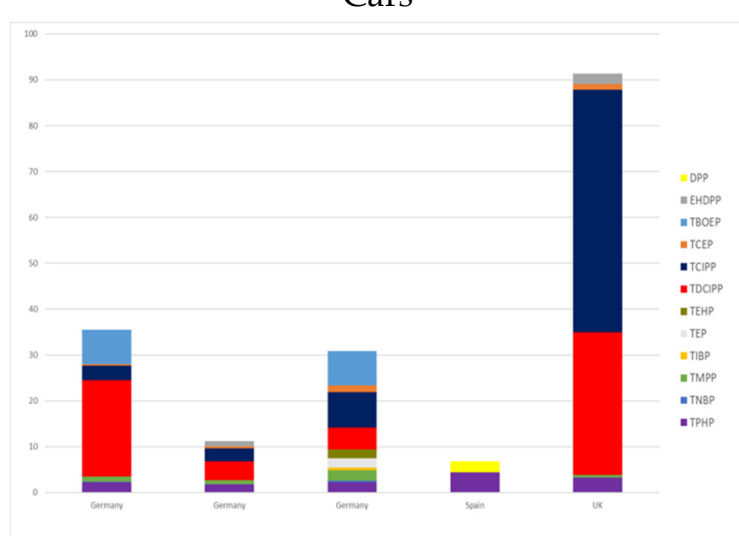

Schools

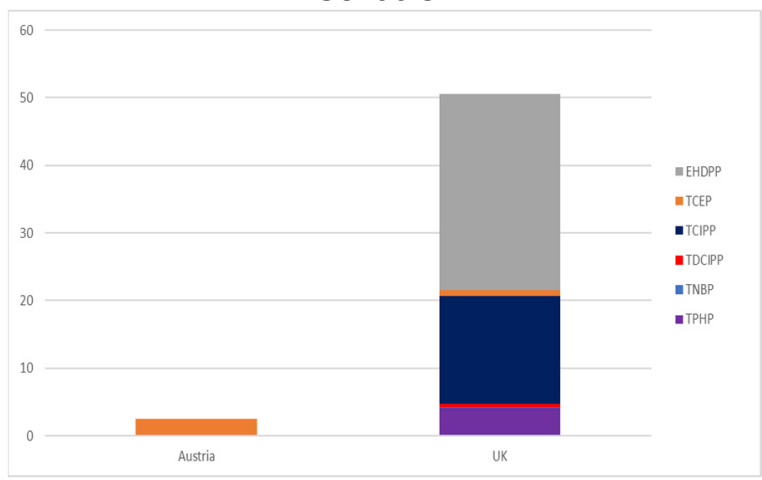

Figure 1. Cont. 
Daycare centers

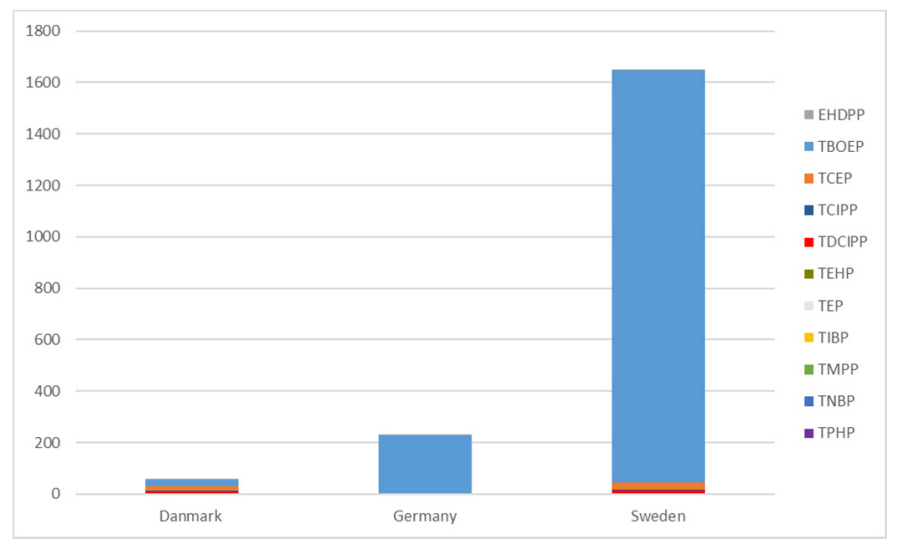

Figure 1. Organophosphorus Flame Retardants (OPFRs) dust median concentration in Europe, 2008-2018 ( $\mu \mathrm{g} / \mathrm{g})$.

To conclude on OPFRs in dust, TBOEP, TCIPP and TDCIPP were the most concentrated in Europe. In homes, offices and cars, the predominant compound was TCIPP, whereas in daycare centers it was TBOEP. TDCIPP was found to be much higher in dust from vehicles and offices than in dust from the main living areas. These findings confirm those of previous review by Wei [39], who also mentioned high concentrations of TBOEP in home dust in non-European countries such as Japan. In addition, this update highlights that, in a given environment, OPFR concentrations in dust tend to be higher in the UK than in the rest of Europe, likely in line with more stringent fire safety regulations in the UK.

\subsubsection{Air}

A total of 10 studies [19-21,27,36,37,40-43] dealt with the contamination of indoor air in Europe and are presented in detail in Table S3. A total of 16 OPFRs were detected; median concentrations ranged from $0.001 \mathrm{ng} / \mathrm{m}^{3}$ in homes in the Czech Republic [36] to $330 \mathrm{ng} / \mathrm{m}^{3}$ in offices in Sweden [41]. However, the passive sampling technique (polyurethane foam) used by Vykoukalová may underestimate air concentrations by sampling, principally, the gas phase, contrary to other studies with active sampling. The five OPFRs with the highest median concentrations were: TCIPP $\left(\right.$ median $=330 \mathrm{ng} / \mathrm{m}^{3}$ in offices in Sweden) $>$ TNBP $\left(\right.$ median $=49 \mathrm{ng} / \mathrm{m}^{3}$ in Germany daycare centers) $>$ TDCIPP $\left(\right.$ median $=28 \mathrm{ng} / \mathrm{m}^{3}$ in offices in Sweden) $>$ TCEP $\left(\right.$ median $=25 \mathrm{ng} / \mathrm{m}^{3}$ in daycare centers in Sweden) > TIBP (median $=13 \mathrm{ng} / \mathrm{m}^{3}$ in homes in Sweden).

We describe hereafter the most recent (>2012) publications investigating indoor air contamination since the previous review by Wei [39], and have thus not included this in our investigation. In homes, air concentrations were measured in four countries: Sweden, Norway, the Czech Republic and Belgium. The concentrations of detected compounds are displayed in Figure 2. With the exception of Belgium (all median < LOD), countries had similar concentration profiles with a predominance of TCIPP followed by TNBP. However, the median TCIPP concentration was between 2 and 10 times higher in Norway than in Sweden or the Czech Republic. In daycare centers (Figure 2), TNBP and TCIPP were measured only in Germany, with TNBP being 25 times more concentrated than TCIPP. In offices (Figure 2), TCIPP largely predominates in Sweden and Germany, with median concentrations being 10 times higher in Sweden. Samples from schools were collected in Germany and Sweden (Figure 2). In Germany, TCIPP, TNBP and TIBP were measured with a similar contribution of TCIPP and TNBP, while in Sweden, only TPHP was analyzed. No study was found that included air sample measurements from cars. 


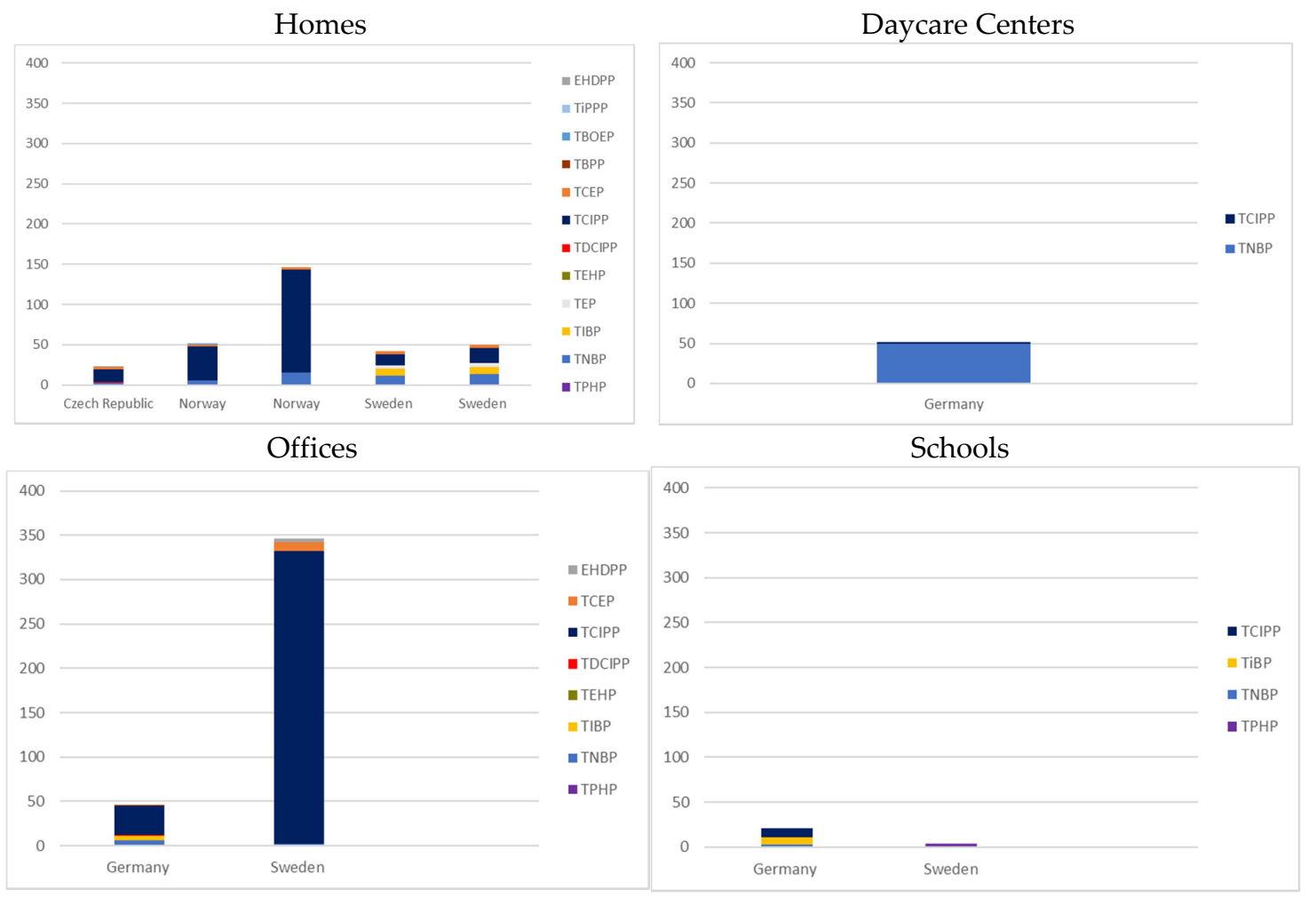

Figure 2. OPFRs air median concentration in Europe, 2000-2018 (ng/m³) (one bar per article).

To conclude on European indoor air, the two predominant compounds in air were TCIPP and TNBP, thus confirming previous findings from Wei, who noticed it was not specific to Europe [39]. TCIPP dominated in homes and offices, followed by TNBP, whereas in German daycare centers TNBP concentrations were higher than those of TCIPP.

Overall, on indoor air and dust contamination, 16 OPFRs were measured in air and 30 in dust. We should note that a comparison between all of these studies might be limited by possible heterogeneity in the detection limits and analytical protocols. We did not consider these elements in detail in this review and assume that among the most recent studies in Europe technical heterogeneities are likely to be small and only slightly influential on the present conclusions. The number of collected samples, the measured compounds and the sampling might also differ between studies. Globally, TBOEP and TDCIPP were more concentrated in dust than in air, in line with their log Koa (13.1 and 10.6, respectively). Conversely, TNBP was present in air with a log Koa of 8.2. TCIPP also has a log Koa of 8.2 and was measured at a high concentration in both indoor matrices. Considering the findings, it would be useful to document more broadly the presence of, at least, these main OPFRs in air and dust of living spaces in Europe, considering more countries, and ideally on representative samples of homes, schools, an daycare centers.

\subsection{Human Exposure to OPFRs in Europe}

\subsubsection{Intake Estimation}

Because of the frequent occurrence of OPFRs in dust and air, humans are exposed to these pollutants via dust ingestion, dermal contact and inhalation, in addition to dietary intake [39]. Several studies have estimated OPFR intake using a similar concentration in the environment, ingestion rates and time-activity patterns [39].

Dust ingestion has long been considered the most important pathway for OPFR exposure [44,45]. The median ingestion via dust to the sum of OPFRs was estimated at $6.6 \mathrm{ng} / \mathrm{kg} \mathrm{bw} / \mathrm{d}$ for nonworking adults and $128 \mathrm{ng} / \mathrm{kg}$ bw/d for children in Belgium [46], at $6.5 \mathrm{ng} / \mathrm{kg}$ bw/d for adults and $22.4 \mathrm{ng} / \mathrm{kg}$ 
bw/d for children in Germany [25], at $2.6 \mathrm{ng} / \mathrm{kg} \mathrm{bw} / \mathrm{d}$ for adults and $60.6 \mathrm{ng} / \mathrm{kg}$ bw/d for children living in urban areas in Romania [30], and at $8.9 \mathrm{ng} / \mathrm{kg}$ bw/d for adults in Norway [37]. Sums of OPFRs inform on global intake; however, comparisons are limited because the included compounds may differ from one study to another. Considering compounds separately, a 2015 study by Brommer and Harrad [26] on the UK population, estimated dust ingestion intake at $0.92 \mathrm{ng} / \mathrm{kg}$ bw/d for TCIPP, $0.07 \mathrm{ng} / \mathrm{kg} \mathrm{bw} / \mathrm{d}$ for TDCIPP and $0.03 \mathrm{ng} / \mathrm{kg} \mathrm{bw} / \mathrm{d}$ for TCEP in adults. With a higher frequency of hand-to-mouth behavior in children, Brommer and Harrad (2015) [26] estimated exposure via dust ingestion at $43 \mathrm{ng} / \mathrm{kg}$ bw/d for TCIPP, $4 \mathrm{ng} / \mathrm{kg}$ bw/d for TDCIPP and $1.7 \mathrm{ng} / \mathrm{kg}$ bw/d for TCEP in the UK. Therefore, toddler OPFR intake via dust ingestion was approximately 10 to 20 times higher than in adults in Belgium, Germany, Romania and the UK. Abou-Elwafa Abdallah et al. (2016) [47] estimated dermal absorption in the UK for TCIPP, TDCIPP and TCEP for adults at 3.8, 0.2 and $0.1 \mathrm{ng} / \mathrm{kg} \mathrm{bw} / \mathrm{d}$ and for toddlers at 32.9, 1.6 and $1.5 \mathrm{ng} / \mathrm{kg} \mathrm{bw} / \mathrm{d}$, respectively. Dermal intakes were thus higher than via dust ingestion for these three OPFRs for UK adults. The contrary was true for UK children, and also for many OPFRs in car dust in Greece [28], notably for TBOEP and TPHP, which are not volatile making the ingestion of dust the main exposure route. Data suggest that inhalation (including both gaseous and particulate phases) exposure may also be an important pathway [48] especially for more volatile compounds such as TCEP or TCIPP [37]. In Norway, the adult median inhalation exposure to OPFRs was $9.3 \mathrm{ng} / \mathrm{kg} \mathrm{bw} / \mathrm{d}$, which is similar to dust ingestion exposure (8.9 $\mathrm{ng} / \mathrm{kg} \mathrm{bw} / \mathrm{d})$ [37].

Overall, major indoor pathways seem to differ from one OPFR to another. In European populations, dust ingestion was the major exposure pathway for TBOEP and TPHP, while inhalation was the major exposure route for TCIPP and TCEP. Unlike EHDPP, dietary exposure is negligible for TBOEP, TPHP, TCIPP and TCEP [22]. Dermal absorption is a minor pathway for EHDPP, TBOEP, TCIPP, TCEP and TPHP [22]. No European data were found concerning a major pathway for TDCIPP. However, these observations are issued from few studies with diverse protocols, OPFRs of interest and microenvironments; a comprehensive and systematic study on exposure routes of main OPFRs would be of great interest.

\subsubsection{Human Biological Measurements of Exposure}

A total of 12 studies that reported concentrations of OPFRs or their metabolites (presented in Table S1 with their parent compounds) in more than ten human samples were identified and reviewed [15,21,35,49-57]. Metabolites were measured in urine, whereas OPFR parents' compounds were measured in hair and milk. OPFRs and metabolites analyzed in matrices were not exactly the same between articles. These studies were conducted in Germany, Belgium, Norway, Sweden and Spain. The data are summarized in Figure 3 (only detected chemicals are displayed) and detailed in supplemental information (Table S4).

A total of 15 metabolites were measured in urinary samples (Figure 3 for detected compounds): Diethyl phosphate (DEP, metabolite of TEP), Bis(2-butoxyethyl) phosphate (BBOEP), Bis(2-butoxyethyl)-(2-hydroxyethyl) phosphate (BBOEHEP) and Di-(2-butoxyethyl) phosphate (DBOEP) (metabolites of TBOEP), Diphenyl phosphate (DPHP, metabolite of TPHP), Diethylhexyl phosphate (DEHP, metabolite of TEHP), Bis-(2-chlorethyl)-phosphate (BCEP) and Di-(2-chloroethyl) phosphate (DCEP) (metabolites of TCEP), Di-n-butyl phosphate (DnBP, metabolite of TNBP), BDCIPP (metabolite of TDCIPP), Bis(1,3-dichloro-2-propyl) phosphate (BCIPP) and Di-(2-chloroisopropyl) phosphate (DCIPP, metabolite of TCIPP), Di-m-cresyl phosphate (DmCP, metabolite of TmCP), Di-o-cresyl phosphate (DoCP, metabolite of ToCP) and Di-p-cresyl phosphate $(\mathrm{DpCP}$, metabolite of TpCP). Samples of urine were collected in Norway, Germany and Belgium from children aged from 20 months to 12 years and adults. Median concentrations ranged from $0.12 \mathrm{ng} / \mathrm{L}$ for BDCIPP to $3.2 \mathrm{ng} / \mathrm{L}$ for DEP $[51,54]$. 


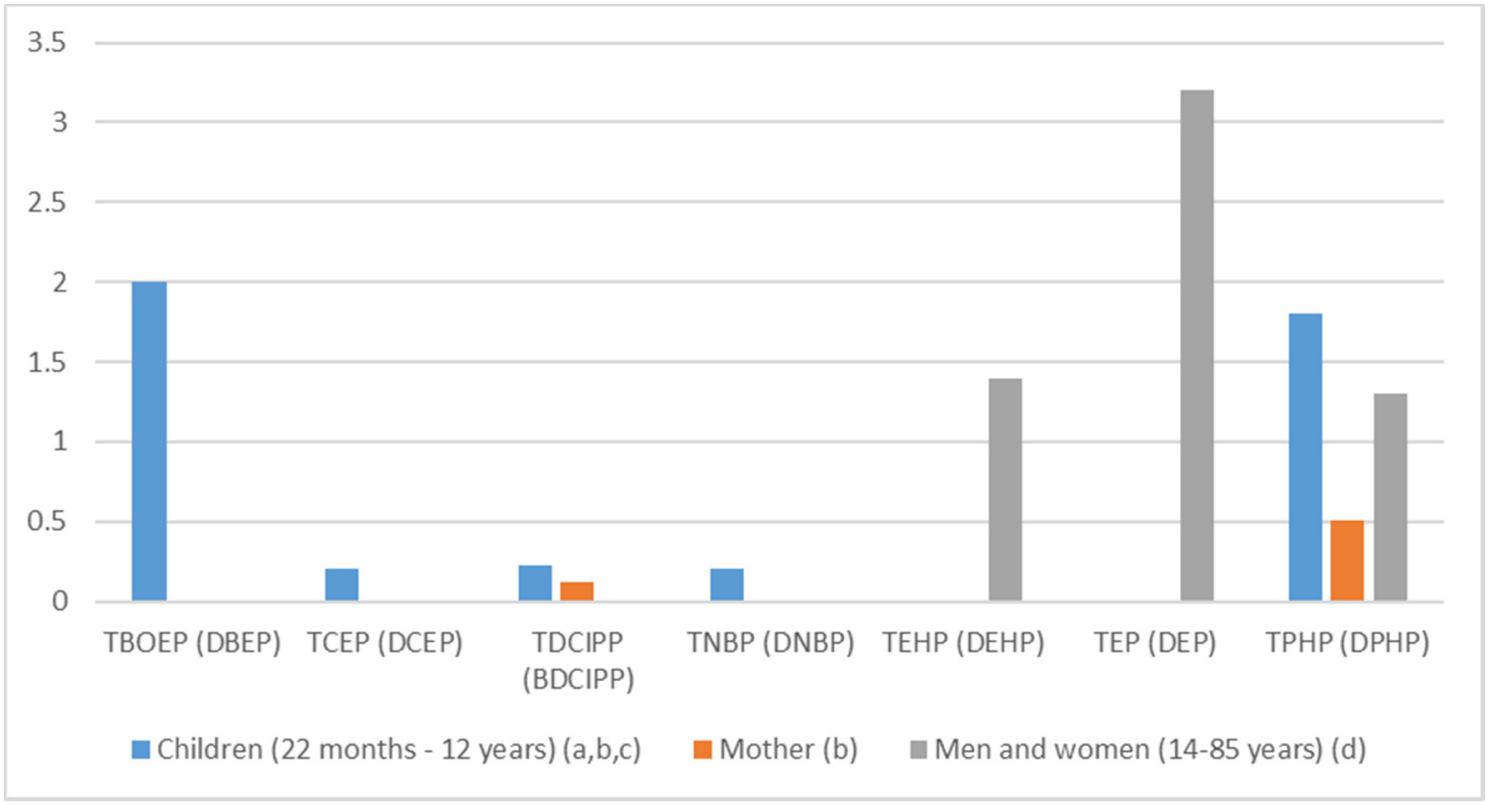

Figure 3. OPFRs (metabolite) highest median urinary concentrations (ng/L) in Europe, 2000-2018 (ng/mL); (a) Fromme et al., 2014 [21]; (b) Cequier et al., 2015 [27]; (c) Larsonn et al., 2014 [53]; (d) Reemtsma et al., 2011 [54].

Compounds having median concentrations of metabolites above $1 \mathrm{ng} / \mathrm{mL}$, were TEP > TBOEP $>$ TPHP > TEHP $[21,51,54]$. In populations including mothers and children (general population, see Figure 3), the metabolite with the highest median concentration was DEP with a median of $3.2 \mathrm{ng} / \mathrm{L}$, followed by DEHP (median $=1.4 \mathrm{ng} / \mathrm{L}$ ) and DPHP (median $=1.3 \mathrm{ng} / \mathrm{L})$ [54].

In children, the two metabolites with the highest concentration were DBOEP (median $=2 \mathrm{ng} / \mathrm{L}$ ) [21] and DPHP (median $=1.8 \mathrm{ng} / \mathrm{L})$ [53].

DBOEP, DBP, DPHP and BDCIPP urinary concentrations were measured in samples from both mothers and children $[21,50,51,53,57]$. DBOEP and DPHP median concentrations were higher in children, whereas DnBP and BDCIPP median concentrations were similar in mothers and children.

The only study to report on OPFR concentrations in hair was conducted in 2012, in Norwegian children aged from 6 to 12 years and their mothers. Seven OPFRs were found: TBOEP, TCEP, TPHP, TDCIPP, EHDPP, TNBP and TMPP (Figure 4). The median concentration ranged from $8 \mathrm{ng} / \mathrm{g}$ for TMPP to $318 \mathrm{ng} / \mathrm{g}$ for TBOEP [52]. The TBOEP median concentration in children was around five times higher than in mothers, while for other OPFRs the median concentrations were similar. Two studies investigated OPFR concentrations in breastmilk in Sweden and Spain $[49,56]$. Fifteen OPFRs were measured, ten were detected and their median concentrations ranked as follows: TCIPP $>$ TMP $>$ TBOEP $>$ TNBP $>$ TPHP $>$ EHDPP $>$ TCEP $>$ TDCIPP $>$ TEP $>$ TMPP (Figure 5). TCIPP was predominant, with a median concentration of $45 \mathrm{ng} / \mathrm{g}$ of lipid weight. Other OPFR median concentrations ranged from 0.8 to $19 \mathrm{ng} / \mathrm{g}$ of lipid weight.

To conclude, OPFRs (or their metabolites) concentrations differ between matrices, likely reflecting different metabolisms. In urine, the OPFR with the highest concentration was DEP (a TEP metabolite), so an estimation of its intake and exposure pathways would be of interest. It is important to stress that DEP is also a degradation product of organophosphorus insecticides such as chlorpyrifos [54]. In children's hair, the most concentrated OPFR was TBOEP, whose intake was high, especially via dust ingestion. The highest concentration in TCEP was noticed in mothers' hair, while the highest concentration of TCIPP was in breastmilk. These OPFRs had a high human intake estimation, mainly via inhalation and dust ingestion [22]. Despite the high TDCIPP human intake via dust ingestion and dermal absorption, concentrations of this OPFR (or its metabolite) in urine, hair and breastmilk appeared very low compared to other OPFRs, which deserves confirmation from other studies. 
Considering their widespread environmental occurrence, the biomonitoring of OPFR is likely to develop in the coming years. A great expectation is a comprehensive strategy on the search for metabolites or parent compounds in human matrices, before representative surveys could occur on large populations.

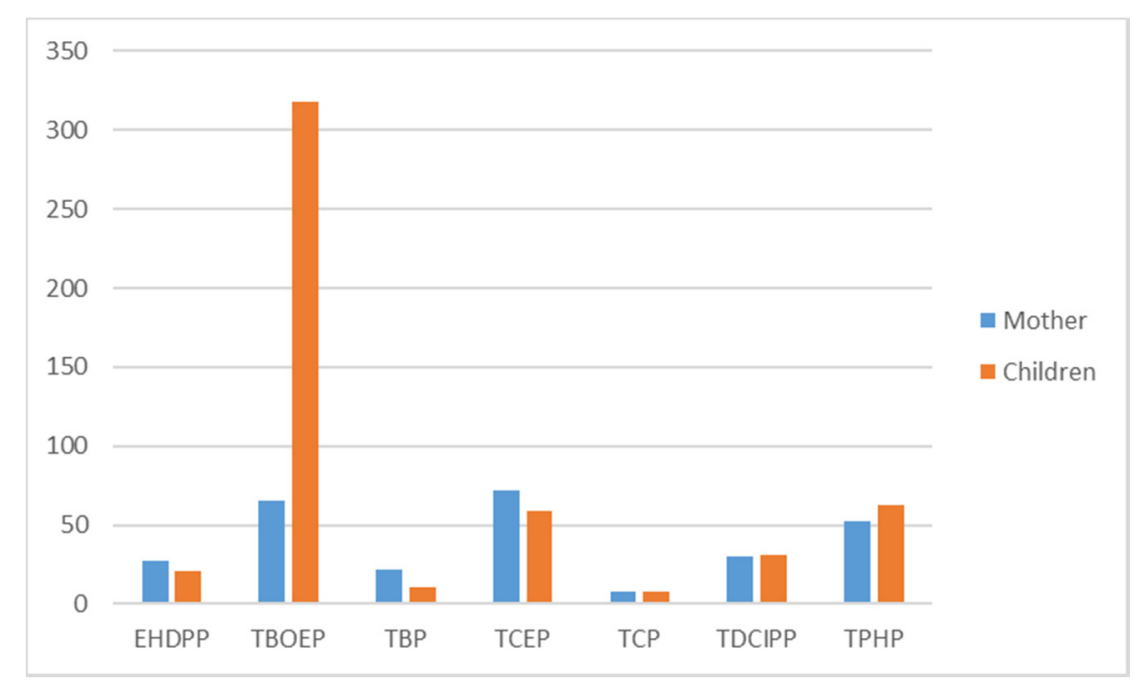

Figure 4. Median OPFR concentrations found in hair in Europe, 2000-2018 [51] (ng/g).

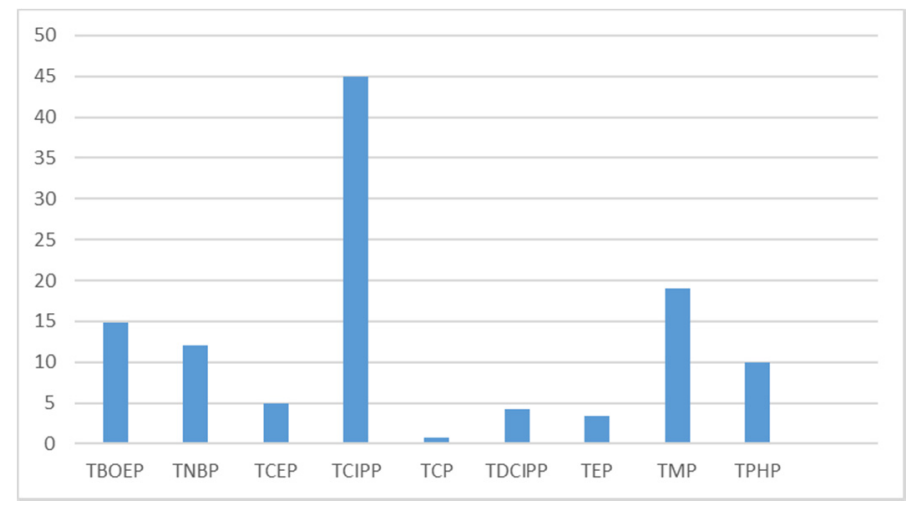

Figure 5. Maximal median OPFR concentrations found in breastmilk in Europe, 2000-2019 (ng/g of lipid weight) $[49,56]$.

This broad review allows us to put indoor concentrations and human exposure in Europe into perspective. TCIPP, TDCIPP and TBOEP had the highest median concentrations in dust samples, and logically the highest estimation for dust ingestion intake. Specifically, TBOEP was measured at high concentrations in daycare centers, but only in Germany, and in children's hair. TCIPP was measured as having a median concentration ten times higher than TBOEP and TDCIPP in maternal milk, consistent with high dust ingestion TCIPP intake.

\subsection{Epidemiological Associations}

Since 2000, 19 epidemiological studies have been assessed, mostly in the USA, on the associations between exposure to OPFRs and health effects in humans, and they are presented in Table 1 [40,58-74]. The health outcomes studied were reproductive, thyroid, neurodevelopmental, respiratory, immunotoxic and dermal. Exposure to OPFRs was assessed using house dust, passive wristband, and urine or blood samples. In these studies, metabolites are specific to the OPFR parent compound, with the exception of the TPHP metabolite, because DPHP is also a metabolite of EHDPP and resorcinol bis(diphenyl phosphate) [58,59]. 
Table 1. Epidemiological evidence on organophosphorus flame retardants, 2000-2019.

\begin{tabular}{|c|c|c|c|c|c|c|c|c|}
\hline Author & Date & Country & Population & Exposure Assessment & Compounds of Interest & Health Outcome & Covariates & Human Health Findings \\
\hline Doherty et al. [58] & 2019 & USA & $\begin{array}{l}227 \text { children of } \\
36 \text { months }\end{array}$ & $\begin{array}{l}\text { Urine sample collected } \\
\text { from mothers between 24- } \\
\text { and 29-week gestation }\end{array}$ & $\begin{array}{l}\text { DPHP, BDCIPP, IP-PPP, and } \\
\text { BCIPHIPP }\end{array}$ & $\begin{array}{l}\text { Children's cognitive function } \\
\text { (Composite, Fine Motor, Visual } \\
\text { Reception, Receptive Language, } \\
\text { Expressive Language was } \\
\text { assessed using the Mullen Scales } \\
\text { of Early Learning (MSEL) at age } \\
\text { between } 2 \text { and } 3 \text { years } \\
\text { Children's language (Vocabulary, } \\
\text { Grammatical Complexity) was } \\
\text { assessed using the } \\
\text { MacArthur-Bates } \\
\text { Communicative Development } \\
\text { Inventories (MB-CDI) at age } \\
\text { between } 2 \text { and } 3 \text { years }\end{array}$ & $\begin{array}{l}\text { Maternal age, education, income, } \\
\text { race/ethnicity, BMI, and } \\
\text { child's sex }\end{array}$ & 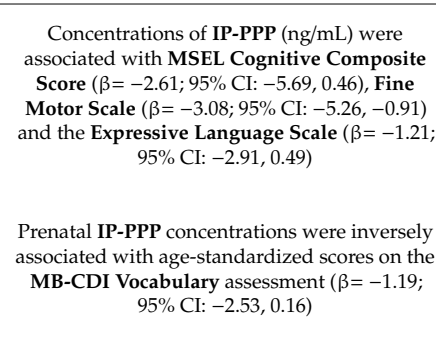 \\
\hline Ait Bamai et al. [59] & 2018 & Japan & 296 children & $\begin{array}{l}\text { House dust samples } \\
\text { collected at age } 7 \\
\text { of children }\end{array}$ & $\begin{array}{l}\text { TMP, TEP, TPP, TBP, TCIP } \\
\text { TCEP, TEHP, TBEP, TDCPP, } \\
\text { TPhP, TCP } \\
\end{array}$ & $\begin{array}{c}\text { Eczema and wheeze were } \\
\text { assessed in children aged } 7 \text { years } \\
\text { using the International Study of } \\
\text { Asthma and Allergies in } \\
\text { Childhood questionnaire }\end{array}$ & $\begin{array}{l}\text { Sex, household income, maternal } \\
\text { smoking, and parental history } \\
\text { of atopy. }\end{array}$ & $\begin{array}{l}\text { Among children without any filaggrin } \\
\text { mutations, TDCIPP was associated with } \\
\text { wheeze (OR: } 1.22,95 \% \text { CI: 1.00-1.48) }\end{array}$ \\
\hline Araki et al. [60] & 2018 & Japan & $\begin{array}{l}113 \text { to } 128 \text { elementary } \\
\text { school-aged children }\end{array}$ & $\begin{array}{l}\text { Urine samples collected } \\
\text { from children }\end{array}$ & 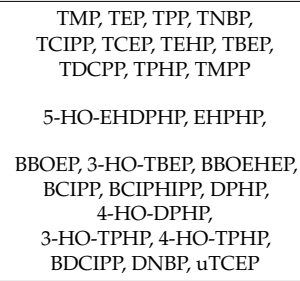 & $\begin{array}{l}\text { International Study of Asthma } \\
\text { and Allergies in Childhood } \\
\text { (ISAAC) questionnaire }\end{array}$ & $\begin{array}{l}\text { Sex, grade, annual income, } \\
\text { dampness index, and creatinine }\end{array}$ & 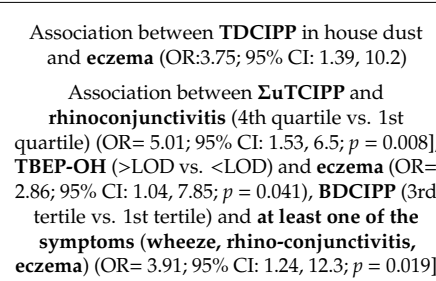 \\
\hline Carignan et al. [61] & 2018 & USA & $\begin{array}{l}211 \text { women from the } \\
\text { Environment and } \\
\text { Reproductive Health } \\
\text { (EARTH) }\end{array}$ & $\begin{array}{l}\text { One or two spot urine } \\
\text { samples per in vitro } \\
\text { fertilization cycle }\end{array}$ & $\begin{array}{l}\text { BCIP, BDCIPP, DPHP, IP-PPP, } \\
\text { tb-PPP }\end{array}$ & $\begin{array}{c}\text { Proportion of fertilized oocytes, } \\
\text { number of best quality embryos, } \\
\text { proportion of cycles resulting in } \\
\text { implantation, clinical pregnancy } \\
\text { and live birth }\end{array}$ & $\begin{array}{l}\text { Year of IVF treatment cycle, } \\
\text { primary infertility diagnosis, and } \\
\text { maternal urinary PFR } \\
\text { metabolites as well as paternal } \\
\text { and maternal age, body mass } \\
\text { index, and race/ethnicity. } \\
\text { Maternal age, body mass index, } \\
\text { race/ethnicity, year of IIF } \\
\text { treatment cycle, and primary } \\
\text { Society for Assisted } \\
\text { Reproductive Technology (SART) } \\
\text { infertility diagnosis at } \\
\text { study entry }\end{array}$ & $\begin{array}{l}\text { Association between the levels of two } \\
\text { individual metabolites (DPHP and tb-PPP) and } \\
\text { of total metabolites, and reduced probability } \\
\text { of successful fertilization, implantation, } \\
\text { clinical pregnancy, and live birth }\end{array}$ \\
\hline Deziel et al. [62] & 2018 & USA & $\begin{array}{l}200 \text { women (100 } \\
\text { papillary thyroid cancer } \\
\text { cases and } 100 \text { controls) }\end{array}$ & Single spot urine samples & $\begin{array}{l}\text { BCIPP, BCIHPP, BDCIPP } \\
\text { IP-PPP, DPHP and tb-PPP }\end{array}$ & & $\begin{array}{l}\text { Age, BMI, education level, family } \\
\text { history of thyroid cancer, } \\
\text { previous benign thyroid disease, } \\
\text { and alcohol consumption }\end{array}$ & $\begin{array}{l}\text { No association between BCIPHIPP, BCIPP, } \\
\text { DPHP, BDCIPP, IP-PPP, tb-PPP and papillary } \\
\text { thyroid cancer (PTC) }\end{array}$ \\
\hline
\end{tabular}


Table 1. Cont.

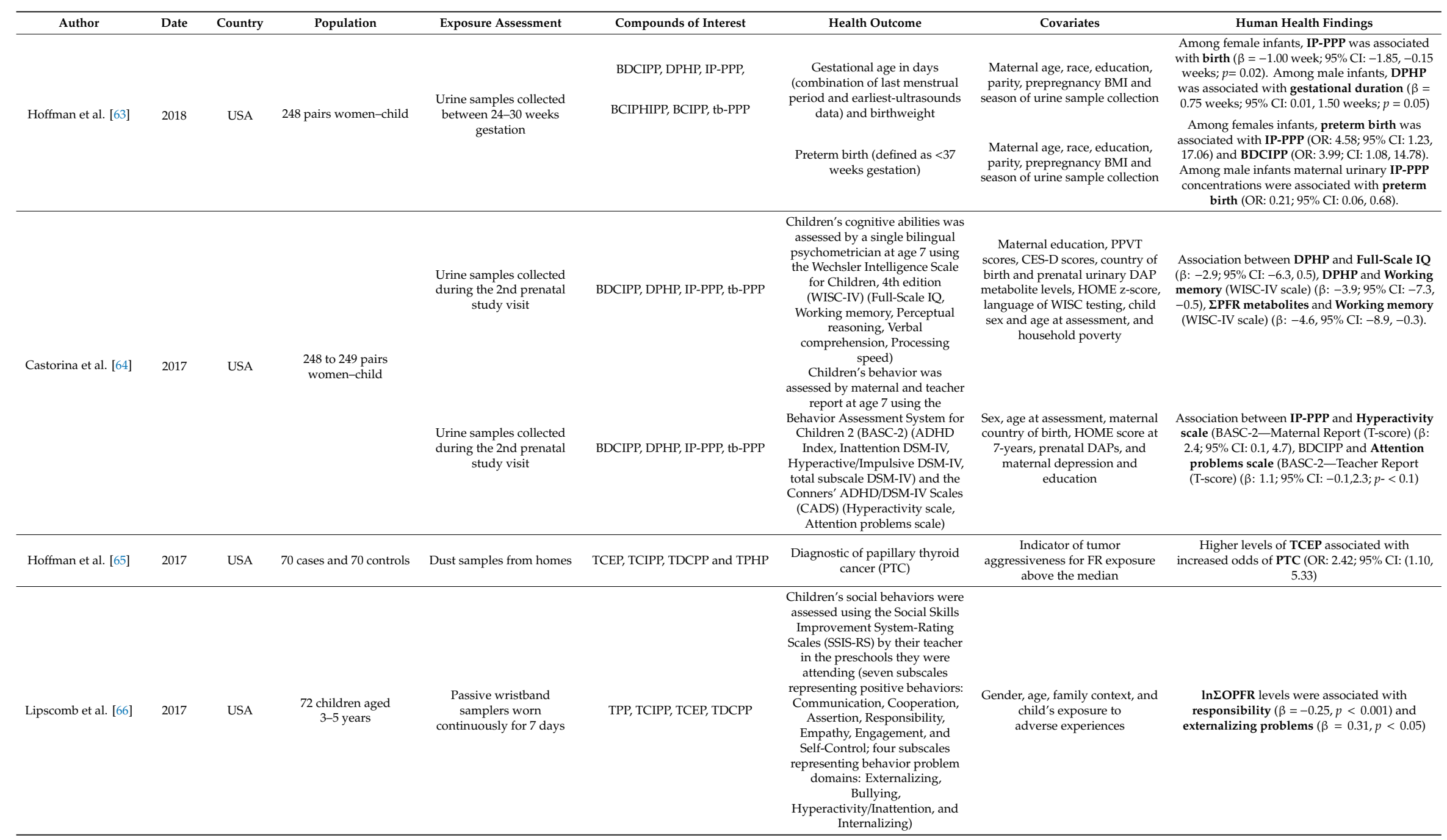


Table 1. Cont.

\begin{tabular}{|c|c|c|c|c|c|c|c|c|}
\hline Author & Date & Country & Population & Exposure Assessment & Compounds of Interest & Health Outcome & Covariates & Human Health Findings \\
\hline \multirow{3}{*}{ Preston et al. [67] } & \multirow{3}{*}{2017} & \multirow{3}{*}{ USA } & 51 adults & $\begin{array}{l}133 \text { urine samples collected } \\
\text { at months } 1,6 \text { and } 12\end{array}$ & DPHP & $\begin{array}{l}\text { Free thyroxine (fT4), total } \\
\text { thyroxine (TT4), total } \\
\text { triiodothyronine (TT3), and } \\
\text { thyroid stimulating hormone } \\
\text { (TSH) in serum samples }\end{array}$ & $\begin{array}{l}\text { Sampling round, time of sample } \\
\text { collection, specific } \\
\text { gravity-corrected iodine and } \\
\text { BDE- } 47 \text { and sex }\end{array}$ & $\begin{array}{l}\text { DPHP was associated with a } 0.43 \mu \mathrm{\mu g} / \mathrm{dL}(95 \% \\
\text { CI: } 0.47,1.36 \text { ) increase in mean TT4 levels }\end{array}$ \\
\hline & & & 25 women & $\begin{array}{l}61 \text { urine samples collected } \\
\text { at months } 1,6 \text { and } 12\end{array}$ & DPHP & $\begin{array}{l}\text { Free thyroxine (fT4), total } \\
\text { thyroxine (TT4), ,total } \\
\text { triodothyronine (TT3), and } \\
\text { thyroid stimulating hormone } \\
\text { (TSH) in serum samples }\end{array}$ & $\begin{array}{l}\text { Sampling round, time of sample } \\
\text { collection, specific } \\
\text { gravity-corrected iodine and } \\
\text { BDE-47 }\end{array}$ & $\begin{array}{l}\text { DPHP was associated with a } 0.91 \mu \mathrm{gg} / \mathrm{dL}(95 \% \\
\text { CI: } 0.47,1.36 \text { ) increase in mean TT4 levels }\end{array}$ \\
\hline & & & $26 \mathrm{men}$ & $\begin{array}{l}61 \text { urine samples collected } \\
\text { at months } 1,6 \text { and } 12\end{array}$ & DPHP & $\begin{array}{l}\text { Free thyroxine (fT4), total } \\
\text { thyroxine (TT4), total } \\
\text { triodothyronine (TT3), and } \\
\text { thyroid stimulating hormone } \\
\text { (TSH) in serum samples }\end{array}$ & $\begin{array}{l}\text { Sampling round, time of sample } \\
\text { collection, specific } \\
\text { gravity-corrected iodine and } \\
\text { BDE-47 }\end{array}$ & $\begin{array}{l}\text { No significant association between DPHP and } \\
\text { TT4, fT } 4 \text {, TT3, TSH }\end{array}$ \\
\hline Soubry et al. [68] & 2017 & USA & $67 \mathrm{men}$ & Urines samples & $\begin{array}{l}\text { BCIP, BDCIPP, DPHP, IP-PPP, } \\
\text { tb-PPP }\end{array}$ & $\begin{array}{l}\text { DNA extracted from sperm } \\
\text { samples }\end{array}$ & $\begin{array}{l}\text { Age, obesity-status and multiple } \\
\text { testing, exposure to } \\
\text { monoisopropylphenyl } \\
\text { diphenyl phosphate }\end{array}$ & $\begin{array}{l}\text { Association between BDCIPP, DPHP, IP-PPP } \\
\text { and hyper- or hypomethylation of different } \\
\text { genes specific to the metabolites }\end{array}$ \\
\hline Canbaz et al. [69] & 2016 & Sweden & $\begin{array}{l}110 \text { children who } \\
\text { developed asthma at } 4 \\
\text { or at } 8 \text { years, matched } \\
\text { with } 110 \text { controls from a } \\
\text { large perspective study }\end{array}$ & $\begin{array}{l}\text { Dust collected from the } \\
\text { mother's mattress two } \\
\text { months after childbirth }\end{array}$ & $\begin{array}{l}\text { TCEP, TCIPP, TDCPP, TBEP, } \\
\text { TPhP, EHDPHP, mmp-TMPP }\end{array}$ & $\begin{array}{l}\text { Asthma at } 4 \text { or } 8 \text { years was } \\
\text { defined based on at least two of } \\
\text { the following three criteria: (i) }>1 \\
\text { episode of wheeze in the last } 12 \\
\text { months; (ii) a doctor's diagnosis } \\
\text { of asthma; (iii) asthma medicine } \\
\text { prescribed occasionally or } \\
\text { regularly over the last } 12 \text { months }\end{array}$ & & $\begin{array}{l}\text { No association between PEFRs concentrations } \\
\text { and development of childhood asthma }\end{array}$ \\
\hline Zhao et al. [70] & 2016 & China & $\begin{array}{l}154 \text { men and } 101 \\
\text { women }\end{array}$ & One blood sample & $\begin{array}{l}\text { TCIPP, TBEP, TPHP, TEP, TNBP, } \\
\text { EHDPP }\end{array}$ & Blood samples & $\begin{array}{l}\text { Negative association between } \\
\text { EHDPP, TPHP, and TNBP levels } \\
\text { and sphingosine } \\
\text { 1-phosphate concentration }\end{array}$ & $\begin{array}{c}\text { Association between levels of the six PEFRs and } \\
\text { increased sphingomyelin concentration ( } p< \\
0.001 \text { for all OPRs). The S1P level in the } \\
\text { highest quartile of EHDPP was } 36 \% \text { lower } \\
\text { (95\% CI: }-39 \%,-33 \% ; p<0.001) \text { than that in } \\
\text { the lowest quartile, } 16 \% \text { lower (95\% CI: }-19 \% \text {, } \\
-14 \% ; p<0.001 \text { ) than that in the highest } \\
\text { TPHP quartile, and } 36 \% \text { lower (95\% CI: }-38 \% \text {, } \\
-33 \% ; p<0.001) \text { than that in the highest } \\
\text { TNBP quartile }\end{array}$ \\
\hline Araki et al. [71] & 2014 & Japan & $\begin{array}{l}516 \text { inhabitants (adults } \\
\text { and children) in } 156 \\
\text { different homes }\end{array}$ & Floor dust & $\begin{array}{l}\text { TMP, TEP, TPP, TNBP, TCIPP, } \\
\text { TCEP, TEHP, TBEP, TDCPP, T } \\
\text { PHP, TMPP }\end{array}$ & $\begin{array}{l}\text { All inhabitants of each home } \\
\text { were asked to complete a } \\
\text { self-administered questionnaire } \\
\text { participants who reported } \\
\text { having received medical } \\
\text { treatment for bronchial asthma, } \\
\text { atopic dermatitis, allergic rhinitis, } \\
\text { and/or allergic conjunctivitis at } \\
\text { any time during the preceding 2 } \\
\text { years were classified as positive }\end{array}$ & $\begin{array}{l}\text { Gender, age, tobacco smoke, } \\
\text { ETS exposure, } \\
\text { recent renovations, wall-to-wall } \\
\text { carpeting, dampness } \\
\text { index, hairffurr-barining pets in } \\
\text { the dwelling, } \\
\text { mechanical ventilition } \\
\text { equipment usage, and total } \\
\text { fungi }\end{array}$ & $\begin{array}{l}\text { Association between TNBP in multi-surface } \\
\text { dust and astha (OR: } 5.34 ; 95 \% \text { CI: } 1.45,19.7) \text {, } \\
\text { TNBP in multi-surface dust and allergic } \\
\text { rhinitis (OR: } 2.55 ; 95 \% \text { CI: 1.29, 45.01) }\end{array}$ \\
\hline
\end{tabular}


Table 1. Cont.

\begin{tabular}{|c|c|c|c|c|c|c|c|c|}
\hline Author & Date & Country & Population & Exposure Assessment & Compounds of Interest & Health Outcome & Covariates & Human Health Findings \\
\hline Meeker et al. [72] & 2013 & USA & $33 \mathrm{men}$ & Urine samples & BDCIPP, DPHP & Blood and semen samples & $\begin{array}{l}\text { Age, BMI, and time of sample } \\
\text { collection, abstinence period }\end{array}$ & 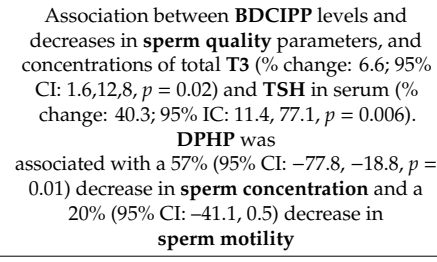 \\
\hline Hutter et al. [32] & 2013 & Austria & 436 children & Air & TCEP, TDCPP & $\begin{array}{l}\text { The cognitive evaluation was } \\
\text { accomplished by a } \\
\text { neurodevelopment test }\end{array}$ & $\begin{array}{c}\text { Social status, gender and region } \\
\text { (urban/rural) }\end{array}$ & $\begin{array}{l}\text { Significant correlations of TCEP in PM10 and } \\
\text { PM2.5 and school dust samples with cognitive } \\
\text { performance. Cognitive performance } \\
\text { decreased with increasing concentrations } \\
\text { of TCEP }\end{array}$ \\
\hline Bergh et al. [40] & 2011 & Sweden & $\begin{array}{l}\text { Adults (men and } \\
\text { women) }\end{array}$ & Air & $\begin{array}{l}\text { TEP, TiPrP, TPrP, TiBP, TBP, TCEP, } \\
\text { TCIPP, TPeP, TTP, TDCPP, TPP, } \\
\text { DPEHP, TEHP, TTOP, d27-TBP cis }\end{array}$ & & & $\begin{array}{l}\text { No association between OPFRs levels and } \\
\text { reported Sick Building Syndrome symptoms }\end{array}$ \\
\hline Kanazawa et al. [73] & 2010 & Japan & $\begin{array}{l}134 \text { adults ( } 70 \text { women } \\
\text { and } 64 \text { men) }\end{array}$ & Floor dust & TBP, ТВEP, TDCPP & & $\begin{array}{l}\text { Age (ordinal variable in } \\
\text { increments of } 10 \text { years), gender, } \\
\text { history of allergy, time spent } \\
\text { athome (h/lay, } 512,>12) \text {, and } \\
\text { condensation and moldy odor }\end{array}$ & 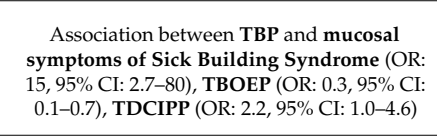 \\
\hline \multirow[t]{2}{*}{ Meeker et al. [74] } & \multirow[t]{2}{*}{2009} & \multirow[t]{2}{*}{ USA } & $38 \mathrm{men}$ & \multirow[t]{2}{*}{ House dust } & \multirow[t]{2}{*}{ TDCPP, TPP } & $\begin{array}{l}\text { Serum and semen samples: } \\
\text { hormones (Free T4, Total I } 3 \text {, } \\
\text { TSH, FSH, LH, Inhibin B, } \\
\text { Testosterone, SHBG, FAI, } \\
\text { estradiol, Prolactin, Sperm } \\
\text { concentration, sperm mobility, } \\
\text { sperm morphology) }\end{array}$ & Age, BMI & 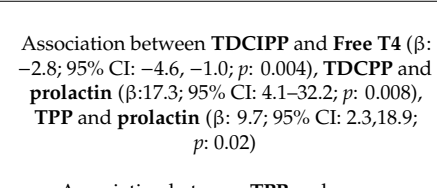 \\
\hline & & & $50 \mathrm{men}$ & & & & Age, BMI and abstinence period & $\begin{array}{c}\text { Association between TPP and sperm } \\
\text { concentration ( } \beta:-18.8 ; 95 \% \text { CI: }-30.1,-4.5 ; \\
p: 0.01)\end{array}$ \\
\hline
\end{tabular}

Bold: Key elements of the table. 
Reproductive functions: Three OPFR, TDCIPP, TPHP and Isopropylated triarylphosphate isomers (ITPs) (or their metabolites) were tested for possible impacts on the reproductive system. Of 201 couples undergoing in vitro fertilization, the urinary TDCIPP metabolite concentrations among the men (though not the women) were associated with a reduced probability of successful oocyte fertilization [61]. In another study, urinary concentrations of the TDCIPP metabolite were cross-sectionally associated with a decrease in both sperm quality parameters (sperm motility, sperm morphology, straight lie velocity and curvilinear velocity) and the thyroid-stimulating hormone (TSH) levels that prompt the thyroid gland to produce hormones [72]. An inverse association was observed between TDCIPP house dust concentrations and occupants' prolactin hormonal levels in serum [74]. Among female infants, the maternal TDCIPP and ITP metabolite concentrations measured in urine samples collected during the late-second or early-third trimester were associated with an increased risk of preterm birth [63]. Conversely, among male infants, the maternal ITP metabolite concentrations measured in urine samples collected during the late-second or early-third trimester were associated with a decreased risk of preterm birth [63]. The TPHP metabolite concentrations measured in urine samples collected during in vitro fecundation from women were inversely associated with the probability of successful fertilization (presence of a fertilized oocyte with two pronuclei 17-20 h after insemination), implantation (defined as a serum $\beta$-hCGlevel $>6 \mathrm{mIU}=\mathrm{mL}$, approximately $17 \mathrm{~d}$ (range $=15-20 \mathrm{~d}$ ) after egg retrieval), clinical pregnancy (the presence of an intrauterine pregnancy confirmed by ultrasound at approximately 6-week gestation) and live birth (defined as the birth of a neonate on or after 24-week gestation) [61]. Another study observed an association between house dust TPHP concentration and decrease in sperm concentration among 50 men from couples that were infertile due to a male factor, a female factor, or a combination of both [74]. The same study observed an association between house dust TPHP concentration and an increase in serum prolactin hormone levels in a population of 38 men [74]. Among male infants, urinary TPHP metabolite concentrations were associated with a modest increase in gestational duration. Baby boys having the highest levels of prenatal TPHP exposure were born approximately 5 days later than those with the lowest levels of exposure [63].

Thyroid systems: Three OPFRs, TDCIPP, TPHP and TCEP (or their metabolites), were tested for possible impacts on the thyroid system. TDCIPP metabolite urinary concentrations were associated with a decrease in concentrations of total triiodothyronine (T3 hormone that helps regulate various physiological processes including growth, metabolism, body temperature and cardiac rhythm), measured cross-sectionally in serum [72]. A positive association was found between TPHP metabolite urinary concentrations and mean total thyroxine levels measured cross-sectionally in serum (T4 hormone, mainly secreted by the thyroid gland, and essential for proper metabolic functioning) among women, but not in men [67]. The TDCIPP urinary metabolite concentrations measured in women from a case-control study (100 cases and 100 controls) were not associated with an increased risk of papillary thyroid cancer [62]. The TCEP concentrations measured in house dust samples were associated with an increased risk of papillary thyroid cancer in women from a case-control study (70 cases and 70 controls) [65].

Neurodevelopmental outcomes: TDCIPP, TPHP and ITP have been studied to assess their effect on neurodevelopment. Prenatal urinary TDCIPP metabolite concentrations were positively associated with attention problems (measured using the Behavior Assessment System for Children-2 scale-Teacher Report) among 7-year-olds [64]. This study found no association between prenatal urinary TDCIPP metabolite concentrations and the hyperactivity scale among children aged 7 [64]. Prenatal urinary TPHP metabolite concentrations were associated with a decrease in intellectual quotient assessed by the Wechsler Intelligence Scale for Children, 4th edition (WISC-IV), among children at age 7, and particularly for the working memory domain [64]. Prenatal urinary ITP metabolite concentration was inversely associated with age-standardized scores on the MacArthur-Bates Communicative Development Inventories vocabulary assessment, Mullen Scales of Early Learning cognitive composite score, fine motor scale and expressive language scale at age 36 months [58]. Furthermore, prenatal concentrations of this metabolite were positively associated with higher scores 
on the hyperactivity scale at age 7 [64] in the California area, where Firemaster ${ }^{\circledR} 550$ (containing ITPs, Great Lakes Solutions, Chemtura Corporation, Philadelphia, PA, USA.) was used.

Respiratory outcomes and immunotoxicity: Three OPFRs, TDCIPP, TCIPP and TNBP, or their metabolites, were tested for possible effects on the respiratory system or immunotoxicity. TDCIPP measured in house dust samples was associated with an increased risk of wheezing in children 7 years of age [59], though not with asthma among children aged 4-8 years [69]. A positive association between urinary TCIPP metabolite concentrations and an increased risk of rhino-conjunctivitis was cross-sectionally observed among children aged 6-12 years [60]. TCIPP measured in house dust two months after birth was not associated with the development of asthma at 4 or 8 years in a case-control study (110 cases and 110 controls) [69]. In the cross-sectional study conducted by Araki et al. [71], the authors did not observe any association between an increased risk of allergic rhinitis in adults and children and TCIPP concentration in house dust. On the contrary, they found a positive association between TNBP concentrations in house dust and risk of asthma among children and adults, as well as an increased risk of allergic rhinitis [60].

Dermal effects: Only one study [60] tested for an association between increased risk of eczema and TDCIPP. Eczema was evaluated using the International Study of Asthma and Allergies in Childhood (ISAAC), while exposure assessed using TDCIPP in house dust and TBOEP urinary metabolites and TCIPP (or its metabolite BCIPP) was cross-sectionally associated with eczema in school-aged children [60].

Other outcomes: Blood concentrations of six OPFRs (TCIPP, TBOEP, TPHP, TEP, TNBP and EHDPP) independently increased sphingomyelin concentrations (which participate in cardiovascular function) in blood among adults [70]. Otherwise, TBOEP indoor concentrations in air were associated with an increased risk of sick building syndrome in Japan [73].

In conclusion, both TDCIPP and TPHP were consistently associated with multiple health outcomes, mainly reproductive. High TCIPP concentrations were possibly associated with adverse respiratory outcomes when exposure was assessed via measurement in human samples, but not when assessed by measurement in indoor environments. Two epidemiological studies associated the ITP urinary metabolite concentrations during pregnancy with various neurodevelopmental outcomes among children in North America. Globally, most epidemiologic studies have addressed relatively modest population sample sizes and thus were limited in statistical power. Considering OPFRs in large epidemiological studies would be useful, especially for compounds widely measured in human environments and matrices such as TBOEP and TNBP.

\section{Conclusions}

Due to an increase in their use, a significant OPFR presence was observed in both indoor environments and human biological matrices in Europe. In this review, we chose to have a broad spectrum from contamination to health effects in humans, complementary to more detailed reviews that exist on specific aspects. We tabulated our findings in Table 2, and summarized them in Figure 6, with the objective to contribute to identifying the prevention and research areas that should be priorities. The most concentrated OPFRs in dust were TBOEP, TCIPP and TDCIPP, and in the air, TCIPP and TNBP. These OPFRs deserve to be studied in more microenvironments in larger and representative surveys. Of these OPFRs, both TBOEP and TCIPP were also found to have the highest concentrations in human matrices, especially among children. TDCIPP and TNBP were also observed in human matrices, however these were among the lowest concentrations. These findings rely on few studies and need to be confirmed on larger representative samples. TDCIPP is one of the most investigated OPFRs in association studies, and has been linked with multiple health outcomes, while TPHP is associated with reproductive outcomes. Considering widespread exposure and epidemiological evidence for these two OPFRs, health risk assessment, including a more systematic assessment of relative importance of different microenvironments and exposure routes, may be useful in informing decision making about preventive actions. While TBOEP and TNBP were frequently found in both indoor environments 
and human matrices, especially in children, association studies have mostly investigated respiratory outcomes, so epidemiological studies would be a priority for these compounds. Table 2 also indicates that several OPFRs have occasionally been studied and detected indoors, so both confirmation studies and a search in biological matrices would be of interest. Lastly, there is a lack of European data concerning Isopropylphenyl phenyl phosphate (IP-PPP) concentrations in both indoor environments and human matrices that must be investigated. Moreover, its classification as potentially neurotoxic and reprotoxic for the fetus (Vermont Department of Health) might incite further epidemiological studies with enough statistical power to assess a potential effect on neurodevelopmental outcomes. More generally, neurodevelopmental outcomes appear to have been studied less than other health effects and may deserve specific attention.

Table 2. Summary of OPFRs indoor contamination, population exposure in Europe and epidemiologic evidence.

\begin{tabular}{|c|c|c|c|c|c|c|c|}
\hline \multirow{2}{*}{ Compound } & \multirow{2}{*}{$\begin{array}{c}\text { Indoor } \\
\text { Contamination }\end{array}$} & \multirow{2}{*}{$\begin{array}{c}\text { Human } \\
\text { Exposure }\end{array}$} & \multicolumn{5}{|c|}{ Epidemiological Evidence of Adverse Effect } \\
\hline & & & Reproductive & Thyroid & Respiratory/Immune & Neuro-Development & Dermal \\
\hline ВСMP-ВСЕР & & & & & & & \\
\hline BDP & & & & & 口 & & \\
\hline DPHP & & $\boldsymbol{\square}$ & & & & & \\
\hline EHDPP & & - & & & - & & $=$ \\
\hline iDDPHP & & & & & & & \\
\hline iDPP & & & & & & & \\
\hline ITP & & & - & $=$ & & - & \\
\hline PBDPP & & & & & & & \\
\hline ТВОЕР & & $\boldsymbol{\square}$ & & & - & & - \\
\hline ТВРР & & & & & & & \\
\hline TCEP & & घ & & - & ㅁ & - & - \\
\hline TCIPP & & $\square$ & $=$ & $\square$ & - & - & $=$ \\
\hline TDBPP & $=$ & & & & & & \\
\hline TDCIPP & & 口 & a & - & $=$ & - & $=$ \\
\hline TEHP & & $=$ & & & ㅁ. & & - \\
\hline
\end{tabular}


Table 2. Cont

\begin{tabular}{|c|c|c|c|c|c|c|c|}
\hline \multirow{2}{*}{ Compound } & \multirow{2}{*}{$\begin{array}{c}\text { Indoor } \\
\text { Contamination }\end{array}$} & \multirow{2}{*}{$\begin{array}{l}\text { Human } \\
\text { Exposure }\end{array}$} & \multicolumn{5}{|c|}{ Epidemiological Evidence of Adverse Effect } \\
\hline & & & Reproductive & Thyroid & Respiratory/Immune & Neuro-Development & Dermal \\
\hline TEP & & $\boldsymbol{\square}$ & & & $\square$ & & - \\
\hline THP & & & & & $=$ & & \\
\hline TIBP & & & & & & & \\
\hline TIPP & & & & & $=$ & & \\
\hline TiPPP & & & & & & & \\
\hline TmCP & & - & & & & & \\
\hline TMP & & $\mathbf{a}$ & & & $=$ & & $w$ \\
\hline TMPP & & $\boldsymbol{\square}$ & & & $=$ & & $=$ \\
\hline TNBP & & $\square$ & & & 口 & & $=$ \\
\hline ToCP & & $=$ & & & & & \\
\hline $\mathrm{TpCP}$ & & - & & & & & \\
\hline TPEP & & & & & & & \\
\hline TPHP & & $\square$ & ש & $\mathbf{z}$ & $=$ & $\boldsymbol{E}$ & $=$ \\
\hline ТРР & 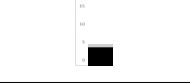 & & $=$ & $=$ & $=$ & $=$ & $=$ \\
\hline TXP & - & & & & & & \\
\hline
\end{tabular}




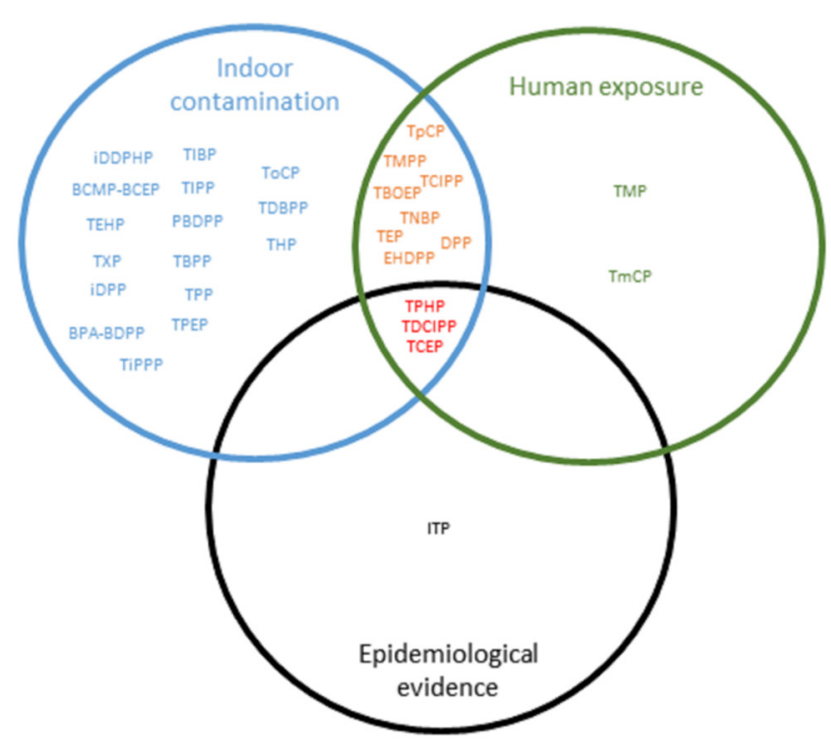

Figure 6. Schematic overview of indoor contamination, human exposure in Europe and epidemiologic evidence of organophosphorus flame retardants. 2000-2019.

Supplementary Materials: The following are available online at http://www.mdpi.com/1660-4601/17/18/6713/s1, Table S1. OPFRs abbreviation; Table S2. Concentrations of OPFRs in indoor dust ( $\mu \mathrm{g} / \mathrm{g})$, Europe, 2000-2018; Table S3. Concentrations of OPFRs in indoor air $\left(\mathrm{ng} / \mathrm{m}^{3}\right)$, Europe, 2000-2018; Table S4. Human exposure to OPFRs, Europe, 2000-2019.

Author Contributions: Conceptualization, P.G. and C.C.; Methodology, all authors; Formal Analysis, Z.C.; Investigation, Z.C.; Writing-Original Draft Preparation, Z.C.; Writing-Review and Editing, Z.C., N.B., F.M.; B.L.B., C.C., P.G.; Visualization, Z.C.; Supervision, P.G. and C.C.; Project Administration, P.G.; Funding Acquisition, P.G. and B.L.B. All authors have read and agreed to the published version of the manuscript.

Funding: This work was supported by the French National Research Agency (ANR) (grant number ANR-16-CE34-0004-01).

Acknowledgments: The authors thank Jane Roffe for language editing.

Conflicts of Interest: The funders had no role in the design of the study; in the collection, analyses, or interpretation of data; in the writing of the manuscript, or in the decision to publish the results.

\section{References}

1. Kemmlein, S.; Hahn, O.; Jann, O. Emissions of organophosphate and brominated flame retardants from selected consumer products and building materials. Atmos. Environ. 2003, 37, 5485-5493. [CrossRef]

2. European Flame Retardant Association. Frequently Asked Questions on Flame Retardants. Available online: https://docplayer.net/11069706-Flame-retardants-frequently-asked-questions-theeuropean-flame-retardants-association.html (accessed on 10 July 2020).

3. Building Evidence for Health. Available online: https://buildingevidence.forhealth.org/wp-content/uploads/ sites/2/2017/05/ForHealth.org_FlameRetardants.pdf (accessed on 10 July 2020).

4. Blum, A.; Behl, M.; Birnbaum, L.S.; Diamond, M.L.; Phillips, A.; Singla, V.; Sipes, N.S.; Stapleton, H.M.; Venier, M. Organophosphate Ester Flame Retardants: Are They a Regrettable Substitution for Polybrominated Diphenyl Ethers? Environ. Sci. Technol. Lett. 2019, 6, 638-649. [CrossRef] [PubMed]

5. European Commission. Commission Regulation (EU) 2017/227 of 9 February 2017 Amending Annex XVII to Regulation (EC) No 1907/2006 of the European Parliament and of the Council Concerning the Registration, Evaluation, Authorisation and Restriction of Chemicals (REACH) as Regards Bis(Pentabromophenyl)Ether. Available online: http://data.europa.eu/eli/reg/2017/227/oj (accessed on 12 September 2020).

6. European Union Comission Directive. Directive 2014/79/EU. Available online: https://eur-lex.europa.eu/ legal-content/FR/TXT/HTML/?uri=CELEX:32014L0079 (accessed on 12 September 2020). 
7. European Union Comission Directive. Directive 2003/11/EC of the European Parliament and of the Council of 6 February 2003 Amending for the 24th time Council Directive 76/769/EEC Relating to Restrictions on the Marketing and Use of Certain Dangerous Substances and Preparations (Pentabromodiphenyl Ether, Octabromodiphenyl Ether). Available online: https://eur-lex.europa.eu/LexUriServ/LexUriServ.do?uri=OJ:L: 2003:042:0045:0046:EN:PDF (accessed on 3 June 2019).

8. Stockholm Convention, UNEP/POPS/POPRC.4/18 Listing of Tetrabromodiphenyl Ether and Pentabromodiphenyl Ether. Available online: https:/www.google.com/url?sa=t\&rct=j\&q=\&esrc= s\&source=web\&cd=\&ved=2ahUKEwiOuZmNqurrAhVFzKQKHZseBscQFjAAegQIBRAB\&url=http $\%$ 3A\%2F\%2Fchm.pops.int\%2FPortals\%2F0\%2Fdownload.aspx\%3Fd\%3DUNEP-POPS-COP.4-SC-4-18. English.pdf\&usg=AOvVaw0DuNRdjspaLgaK481RHSln (accessed on 14 September 2020).

9. Covaci, A.; Harrad, S.; Abdallah, M.A.-E.; Ali, N.; Law, R.J.; Herzke, D.; de Wit, C.A. Novel brominated flame retardants: A review of their analysis, environmental fate and behaviour. Environ. Int. 2011, 37, 532-556. [CrossRef] [PubMed]

10. Van der Veen, I.; de Boer, J. Phosphorus flame retardants: Properties, production, environmental occurrence, toxicity and analysis. Chemosphere 2012, 88, 1119-1153. [CrossRef] [PubMed]

11. Pinfa. Non-Halogenated Phosphorus, Inorganic and Nitrogen Flame Retardants 2017. Available online: https://www.pinfa.eu/wp-content/uploads/2018/05/pinfa_BC_edit-2017-web.pdf (accessed on 10 July 2020).

12. Andresen, J.A.; Grundmann, A.; Bester, K. Organophosphorus flame retardants and plasticisers in surface waters. Sci. Total Environ. 2004, 332, 155-166. [CrossRef]

13. Mendelsohn, E.; Hagopian, A.; Hoffman, K.; Butt, C.M.; Lorenzo, A.; Congleton, J.; Webster, T.F.; Stapleton, H.M. Nail polish as a source of exposure to triphenyl phosphate. Environ. Int. 2016, 86, 45-51. [CrossRef]

14. Marklund, A.; Andersson, B.; Haglund, P. Traffic as a Source of Organophosphorus Flame Retardants and Plasticizers in Snow. Environ. Sci. Technol. 2005, 39, 3555-3562. [CrossRef]

15. Schindler, B.K.; Weiss, T.; Schütze, A.; Koslitz, S.; Broding, H.C.; Bünger, J.; Brüning, T. Occupational exposure of air crews to tricresyl phosphate isomers and organophosphate flame retardants after fume events. Archiv. Toxicol. 2013, 87, 645-648. [CrossRef]

16. Kojima, H.; Takeuchi, S.; Itoh, T.; Iida, M.; Kobayashi, S.; Yoshida, T. In vitro endocrine disruption potential of organophosphate flame retardants via human nuclear receptors. Toxicology 2013, 314, 76-83. [CrossRef]

17. Behl, M.; Hsieh, J.-H.; Shafer, T.J.; Mundy, W.R.; Rice, J.R.; Boyd, W.A.; Freedman, J.H.; Hunter, E.S.; Jarema, K.A.; Padilla, S.; et al. Use of alternative assays to identify and prioritize organophosphorus flame retardants for potential developmental and neurotoxicity. Neurotoxicol. Teratol. 2015, 52, 181-193. [CrossRef]

18. Langer, S.; Fredricsson, M.; Weschler, C.J.; Bekö, G.; Strandberg, B.; Remberger, M.; Toftum, J.; Clausen, G. Organophosphate esters in dust samples collected from Danish homes and daycare centers. Chemosphere 2016, 154, 559-566. [CrossRef] [PubMed]

19. Bergh, C.; Torgrip, R.; Emenius, G.; Östman, C. Organophosphate and phthalate esters in air and settled dust-A multi-location indoor study: Organophosphate and phthalate esters in air and settled dust. Indoor Air 2011, 21, 67-76. [CrossRef] [PubMed]

20. Luongo, G.; Östman, C. Organophosphate and phthalate esters in settled dust from apartment buildings in Stockholm. Indoor Air 2016, 26, 414-425. [CrossRef] [PubMed]

21. Fromme, H.; Lahrz, T.; Kraft, M.; Fembacher, L.; Mach, C.; Dietrich, S.; Burkardt, R.; Völkel, W.; Göen, T. Organophosphate flame retardants and plasticizers in the air and dust in German daycare centers and human biomonitoring in visiting children (LUPE 3). Environ. Int. 2014, 71, 158-163. [CrossRef] [PubMed]

22. Xu, F.; Tay, J.-H.; Covaci, A.; Padilla-Sánchez, J.A.; Papadopoulou, E.; Haug, L.S.; Neels, H.; Sellström, U.; de Wit, C.A. Assessment of dietary exposure to organohalogen contaminants, legacy and emerging flame retardants in a Norwegian cohort. Environ. Int. 2017, 102, 236-243. [CrossRef]

23. Ballesteros-Gómez, A.; Aragón, Á.; Van den Eede, N.; de Boer, J.; Covaci, A. Impurities of Resorcinol Bis(Diphenyl Phosphate) in Plastics and Dust Collected on Electric/Electronic Material. Environ. Sci. Technol. 2016, 50, 1934-1940. [CrossRef]

24. Björnsdotter, M.K.; Romera-García, E.; Borrull, J.; de Boer, J.; Rubio, S.; Ballesteros-Gómez, A. Presence of diphenyl phosphate and aryl-phosphate flame retardants in indoor dust from different microenvironments in Spain and the Netherlands and estimation of human exposure. Environ. Int. 2018, 112, 59-67. [CrossRef] 
25. Brommer, S.; Harrad, S.; Van den Eede, N.; Covaci, A. Concentrations of organophosphate esters and brominated flame retardants in German indoor dust samples. J. Environ. Monit. 2012, 14, 2482. [CrossRef]

26. Brommer, S.; Harrad, S. Sources and human exposure implications of concentrations of organophosphate flame retardants in dust from UK cars, classrooms, living rooms, and offices. Environ. Int. 2015, 83, 202-207. [CrossRef]

27. Cequier, E.; Ionas, A.C.; Covaci, A.; Marcé, R.M.; Becher, G.; Thomsen, C. Occurrence of a Broad Range of Legacy and Emerging Flame Retardants in Indoor Environments in Norway. Environ. Sci. Technol. 2014, 48, 6827-6835. [CrossRef]

28. Christia, C.; Poma, G.; Besis, A.; Samara, C.; Covaci, A. Legacy and emerging organophosphorus flame retardants in car dust from Greece: Implications for human exposure. Chemosphere 2018, 196, 231-239. [CrossRef] [PubMed]

29. Coelho, S.D.; Sousa, A.C.A.; Isobe, T.; Kim, J.-W.; Kunisue, T.; Nogueira, A.J.A.; Tanabe, S. Brominated, chlorinated and phosphate organic contaminants in house dust from Portugal. Sci. Total Environ. 2016, 569-570, 442-449. [CrossRef] [PubMed]

30. Dirtu, A.C.; Ali, N.; Van den Eede, N.; Neels, H.; Covaci, A. Country specific comparison for profile of chlorinated, brominated and phosphate organic contaminants in indoor dust. Case study for Eastern Romania, 2010. Environ. Int. 2012, 49, 1-8. [CrossRef] [PubMed]

31. Harrad, S.; Brommer, S.; Mueller, J.F. Concentrations of organophosphate flame retardants in dust from cars, homes, and offices: An international comparison. Emerg. Contam. 2016, 2, 66-72. [CrossRef]

32. Hutter, H.-P.; Haluza, D.; Piegler, K.; Hohenblum, P.; Fröhlich, M.; Scharf, S.; Uhl, M.; Damberger, B.; Tappler, P.; Kundi, M.; et al. Semivolatile compounds in schools and their influence on cognitive performance of children. Int. J. Occup. Med. Environ. Health 2013, 26. [CrossRef] [PubMed]

33. Kademoglou, K.; Xu, F.; Padilla-Sanchez, J.A.; Haug, L.S.; Covaci, A.; Collins, C.D. Legacy and alternative flame retardants in Norwegian and UK indoor environment: Implications of human exposure via dust ingestion. Environ. Int. 2017, 102, 48-56. [CrossRef]

34. Sugeng, E.J.; Leonards, P.E.G.; van de Bor, M. Brominated and organophosphorus flame retardants in body wipes and house dust, and an estimation of house dust hand-loadings in Dutch toddlers. Environ. Res. 2017, 158, 789-797. [CrossRef]

35. Van den Eede, N.; Neels, H.; Jorens, P.G.; Covaci, A. Analysis of organophosphate flame retardant diester metabolites in human urine by liquid chromatography electrospray ionisation tandem mass spectrometry. J. Chromatogr. A 2013, 1303, 48-53. [CrossRef]

36. Vykoukalová, M.; Venier, M.; Vojta, Š.; Melymuk, L.; Bečanová, J.; Romanak, K.; Prokeš, R.; Okeme, J.O.; Saini, A.; Diamond, M.L.; et al. Organophosphate esters flame retardants in the indoor environment. Environ. Int. 2017, 106, 97-104. [CrossRef]

37. Xu, F.; Giovanoulis, G.; van Waes, S.; Padilla-Sanchez, J.A.; Papadopoulou, E.; Magnér, J.; Haug, L.S.; Neels, H.; Covaci, A. Comprehensive Study of Human External Exposure to Organophosphate Flame Retardants via Air, Dust, and Hand Wipes: The Importance of Sampling and Assessment Strategy. Environ. Sci. Technol. 2016, 50, 7752-7760. [CrossRef]

38. Zhou, L.; Hiltscher, M.; Püttmann, W. Occurrence and human exposure assessment of organophosphate flame retardants in indoor dust from various microenvironments of the Rhine/Main region, Germany. Indoor Air 2017, 27, 1113-1127. [CrossRef]

39. Wei, G.-L.; Li, D.-Q.; Zhuo, M.-N.; Liao, Y.-S.; Xie, Z.-Y.; Guo, T.-L.; Li, J.-J.; Zhang, S.-Y.; Liang, Z.-Q. Organophosphorus flame retardants and plasticizers: Sources, occurrence, toxicity and human exposure. Environ. Pollut. 2015, 196, 29-46. [CrossRef]

40. Bergh, C.; Magnus Åberg, K.; Svartengren, M.; Emenius, G.; Östman, C. Organophosphate and phthalate esters in indoor air: A comparison between multi-storey buildings with high and low prevalence of sick building symptoms. J. Environ. Monit. 2011, 13, 2001. [CrossRef]

41. Wong, F.; de Wit, C.A.; Newton, S.R. Concentrations and variability of organophosphate esters, halogenated flame retardants, and polybrominated diphenyl ethers in indoor and outdoor air in Stockholm, Sweden. Environ. Pollut. 2018, 240, 514-522. [CrossRef]

42. Zhou, L.; Hiltscher, M.; Gruber, D.; Püttmann, W. Organophosphate flame retardants (OPFRs) in indoor and outdoor air in the Rhine/Main area, Germany: Comparison of concentrations and distribution profiles in different microenvironments. Environ. Sci. Pollut. Res. 2017, 24, 10992-11005. [CrossRef] 
43. Persson, J.; Wang, T.; Hagberg, J. Organophosphate flame retardants and plasticizers in indoor dust, air and window wipes in newly built low-energy preschools. Sci. Total Environ. 2018, 628-629, 159-168. [CrossRef]

44. Alves, A.; Kucharska, A.; Erratico, C.; Xu, F.; Den Hond, E.; Koppen, G.; Vanermen, G.; Covaci, A.; Voorspoels, S. Human biomonitoring of emerging pollutants through non-invasive matrices: State of the art and future potential. Anal. Bioanal. Chem. 2014, 406, 4063-4088. [CrossRef]

45. De Boer, J.; Ballesteros-Gómez, A.; Leslie, H.A.; Brandsma, S.H.; Leonards, P.E.G. Flame retardants: Dust-And not food-Might be the risk. Chemosphere 2016, 150, 461-464. [CrossRef]

46. Van den Eede, N.; Dirtu, A.C.; Neels, H.; Covaci, A. Analytical developments and preliminary assessment of human exposure to organophosphate flame retardants from indoor dust. Environ. Int. 2011, 37, 454-461. [CrossRef] [PubMed]

47. Abou-Elwafa Abdallah, M.; Pawar, G.; Harrad, S. Human dermal absorption of chlorinated organophosphate flame retardants; implications for human exposure. Toxicol. Appl. Pharmacol. 2016, 291, 28-37. [CrossRef]

48. Stapleton, H.M.; Klosterhaus, S.; Eagle, S.; Fuh, J.; Meeker, J.D.; Blum, A.; Webster, T.F. Detection of Organophosphate Flame Retardants in Furniture Foam and US House Dust. Environ. Sci. Technol. 2009, 43, 7490-7495. [CrossRef]

49. Beser, M.I.; Pardo, O.; Beltrán, J.; Yusà, V. Determination of 21 perfluoroalkyl substances and organophosphorus compounds in breast milk by liquid chromatography coupled to orbitrap high-resolution mass spectrometry. Anal. Chim. Acta 2019, 1049, 123-132. [CrossRef] [PubMed]

50. Cequier, E. A high-throughput method for determination of metabolites of organophosphate flame retardants in urine by ultra performance liquid chromatography-high resolution mass spectrometry. Anal. Chim. Acta 2014, 845, 98-104. [CrossRef]

51. Cequier, E.; Sakhi, A.K.; Marcé, R.M.; Becher, G.; Thomsen, C. Human exposure pathways to organophosphate triesters-A biomonitoring study of mother-child pairs. Environ. Int. 2015, 75, 159-165. [CrossRef]

52. Kucharska, A.; Cequier, E.; Thomsen, C.; Becher, G.; Covaci, A.; Voorspoels, S. Assessment of human hair as an indicator of exposure to organophosphate flame retardants. Case study on a Norwegian mother-child cohort. Environ. Int. 2015, 83, 50-57. [CrossRef]

53. Larsson, K.; de Wit, C.A.; Sellström, U.; Sahlström, L.; Lindh, C.H.; Berglund, M. Brominated Flame Retardants and Organophosphate Esters in Preschool Dust and Children's Hand Wipes. Environ. Sci. Technol. 2018, 52, 4878-4888. [CrossRef]

54. Reemtsma, T.; Lingott, J.; Roegler, S. Determination of 14 monoalkyl phosphates, dialkyl phosphates and dialkyl thiophosphates by LC-MS/MS in human urinary samples. Sci. Total Environ. 2011, 409, 1990-1993. [CrossRef]

55. Schindler, B.K.; Förster, K.; Angerer, J. Determination of human urinary organophosphate flame retardant metabolites by solid-phase extraction and gas chromatography-tandem mass spectrometry. J. Chromatogr. B 2009, 877, 375-381. [CrossRef]

56. Sundkvist, A.M.; Olofsson, U.; Haglund, P. Organophosphorus flame retardants and plasticizers in marine and fresh water biota and in human milk. J. Environ. Monit. 2010, 12, 943. [CrossRef]

57. Völkel, W.; Fuchs, V.; Wöckner, M.; Fromme, H. Toxicokinetic of tris(2-butoxyethyl) phosphate (TBOEP) in humans following single oral administration. Arch. Toxicol. 2018, 92, 651-660. [CrossRef]

58. Doherty, B.T.; Hoffman, K.; Keil, A.P.; Engel, S.M.; Stapleton, H.M.; Goldman, B.D.; Olshan, A.F.; Daniels, J.L. Prenatal exposure to organophosphate esters and cognitive development in young children in the Pregnancy, Infection, and Nutrition Study. Environ. Res. 2019, 169, 33-40. [CrossRef]

59. Ait Bamai, Y.; Araki, A.; Nomura, T.; Kawai, T.; Tsuboi, T.; Kobayashi, S.; Miyashita, C.; Takeda, M.; Shimizu, H.; Kishi, R. Association of filaggrin gene mutations and childhood eczema and wheeze with phthalates and phosphorus flame retardants in house dust: The Hokkaido study on Environment and Children's Health. Environ. Int. 2018, 121, 102-110. [CrossRef]

60. Araki, A.; Bastiaensen, M.; Ait Bamai, Y.; Van den Eede, N.; Kawai, T.; Tsuboi, T.; Ketema, R.M.; Covaci, A.; Kishi, R. Associations between allergic symptoms and phosphate flame retardants in dust and their urinary metabolites among school children. Environ. Int. 2018, 119, 438-446. [CrossRef]

61. Carignan, C.C.; Mínguez-Alarcón, L.; Williams, P.L.; Meeker, J.D.; Stapleton, H.M.; Butt, C.M.; Toth, T.L.; Ford, J.B.; Hauser, R. Paternal urinary concentrations of organophosphate flame retardant metabolites, fertility measures, and pregnancy outcomes among couples undergoing in vitro fertilization. Environ. Int. 2018, 111, 232-238. [CrossRef] 
62. Deziel, N.C.; Yi, H.; Stapleton, H.M.; Huang, H.; Zhao, N.; Zhang, Y. A case-control study of exposure to organophosphate flame retardants and risk of thyroid cancer in women. BMC Cancer 2018, 18. [CrossRef]

63. Hoffman, K.; Stapleton, H.M.; Lorenzo, A.; Butt, C.M.; Adair, L.; Herring, A.H.; Daniels, J.L. Prenatal exposure to organophosphates and associations with birthweight and gestational length. Environ. Int. 2018, 116, 248-254. [CrossRef]

64. Castorina, R.; Butt, C.; Stapleton, H.M.; Avery, D.; Harley, K.G.; Holland, N.; Eskenazi, B.; Bradman, A. Flame retardants and their metabolites in the homes and urine of pregnant women residing in California (the CHAMACOS cohort). Chemosphere 2017, 179, 159-166. [CrossRef]

65. Hoffman, K.; Lorenzo, A.; Butt, C.M.; Hammel, S.C.; Henderson, B.B.; Roman, S.A.; Scheri, R.P.; Stapleton, H.M.; Sosa, J.A. Exposure to flame retardant chemicals and occurrence and severity of papillary thyroid cancer: A case-control study. Environ. Int. 2017, 107, 235-242. [CrossRef]

66. Lipscomb, S.T.; McClelland, M.M.; MacDonald, M.; Cardenas, A.; Anderson, K.A.; Kile, M.L. Cross-sectional study of social behaviors in preschool children and exposure to flame retardants. Environ. Health $2017,16$. [CrossRef]

67. Preston, E.V.; McClean, M.D.; Claus Henn, B.; Stapleton, H.M.; Braverman, L.E.; Pearce, E.N.; Makey, C.M.; Webster, T.F. Associations between urinary diphenyl phosphate and thyroid function. Environ. Int. 2017, 101, 158-164. [CrossRef]

68. Soubry, A.; Hoyo, C.; Butt, C.M.; Fieuws, S.; Price, T.M.; Murphy, S.K.; Stapleton, H.M. Human exposure to flame-retardants is associated with aberrant DNA methylation at imprinted genes in sperm. Environ. Epigenet 2017, 3, dvx003. [CrossRef]

69. Canbaz, D.; van Velzen, M.J.M.; Hallner, E.; Zwinderman, A.H.; Wickman, M.; Leonards, P.E.G.; van Ree, R.; van Rijt, L.S. Exposure to organophosphate and polybrominated diphenyl ether flame retardants via indoor dust and childhood asthma. Indoor Air 2016, 26, 403-413. [CrossRef]

70. Zhao, F.; Wan, Y.; Zhao, H.; Hu, W.; Mu, D.; Webster, T.F.; Hu, J. Levels of Blood Organophosphorus Flame Retardants and Association with Changes in Human Sphingolipid Homeostasis. Environ. Sci. Technol. 2016, 50, 8896-8903. [CrossRef]

71. Araki, A.; Saito, I.; Kanazawa, A.; Morimoto, K.; Nakayama, K.; Shibata, E.; Tanaka, M.; Takigawa, T.; Yoshimura, T.; Chikara, H.; et al. Phosphorus flame retardants in indoor dust and their relation to asthma and allergies of inhabitants. Indoor Air 2014, 24, 3-15. [CrossRef]

72. Meeker, J.D.; Cooper, E.M.; Stapleton, H.M.; Hauser, R. Urinary Metabolites of Organophosphate Flame Retardants: Temporal Variability and Correlations with House Dust Concentrations. Environ. Health Perspect. 2013, 121, 580-585. [CrossRef]

73. Kanazawa, A.; Saito, I.; Araki, A.; Takeda, M.; Ma, M.; Saijo, Y.; Kishi, R. Association between indoor exposure to semi-volatile organic compounds and building-related symptoms among the occupants of residential dwellings. Indoor Air 2010, 20, 72-84. [CrossRef]

74. Meeker, J.D.; Johnson, P.I.; Camann, D.; Hauser, R. Polybrominated diphenyl ether (PBDE) concentrations in house dust are related to hormone levels in men. Sci. Total Environ. 2009, 407, 3425-3429. [CrossRef]

(C) 2020 by the authors. Licensee MDPI, Basel, Switzerland. This article is an open access article distributed under the terms and conditions of the Creative Commons Attribution (CC BY) license (http://creativecommons.org/licenses/by/4.0/). 